\title{
The Phases of Transformation to Sustainability (T2S) - Struc- turing the Complexity of Transformations and Sustainability through the Negotiation Perspective
}

\author{
Ariel Macaspac Hernandez 1,* \\ 1 Deutsches Institut für Entwicklungspolitik/German Development Institute; ariel.hernandez@die-gdi.de \\ * Correspondence: ariel.hernandez@die-gdi.de;
}

\begin{abstract}
:
Conventional academic debate on sustainability and transformation has begun to be disputed by researchers, policymakers and other stakeholders from the private sector. The complexity of linking sustainability with transformation necessitates the development of new ways of understanding and explaining actors, processes, issues, structures, and outcomes related to transformation to sustainability (T2S). A persistent problem in understanding and managing the T2S is the implied notion of a monolithic transformation to achieve sustainability. This notion underestimates the diversity of actors as well as the historical contexts of transformations. At the same time, achieving T2S is highly dependent on technical solutions as well as policies that can stir needed behavioural change, whereas these technical solutions and policies are not always socially acceptable or politically implementable. Therefore, achieving T2S also calls for evaluating normative foundations of policies and actions needed to advance T2S. This article argues that T2S is composed of different phases, each of which having a different set of actors, resources and audience. This article explains how collective decision can be achieved through multiple levels and types of negotiations that occur in an orchestrated manner. To understand this, this article introduces a theoretical model as an analytical framework to structure how T2S unfolds. This model uses insights from negotiation studies to focus on the actors' perspectives on T2S. It proposes the division of the transformation process into phases - entry point, learning, sequencing, disrupting and fortifying. Using the Germany's energy transition (Energiewende), each of these phases is analysed to determine the "quality" of cooperation that can help fulfil the tasks required to master the so-called "cognitive games" of T2S (ripeness game, power game, bargaining game, policy game, scaling game). Moreover, insights are presented to explain how the designated milestone can be achieved that indicates the advancing to the next phase and eventually entrench the transformation process. The lessons and findings resulting from the analysis of the phases of T2S suggest that there is also the need to revisit underlying assumptions on negotiations, sustainability and transformation.
\end{abstract}

Keywords: Transformation; sustainability; negotiation; German Energiewende; complexity; decisions; phases of processes; cooperation

\section{Introduction - Negotiation Studies as a "Practical" Perspective to the Transfor- mation to Sustainability}

The complexity of sustainability and transformation is responsible to the heterogeneity of sustainability transformations research [1-3]. This heterogeneity can easily overwhelm policymakers and the society-at-large particularly when current concepts, methodologies, and approaches tend to focus only on one or few aspects of transformation to sustainability. Therefore, this complexity necessitates the development of new ways of integrative and holistic understanding and explaining actors, processes, issues, structures, 
and outcomes related to transformation to sustainability. The current political dividedness in several countries is increasingly referred to as "culture wars" [4,5] where important sustainability issues such as equality and climate protection are embedded into a wider spectrum of grievances and into a wider context of conflict.

The various unaddressed conundrums of sustainable development manifest the complexity of multiple transitions and parallel transformations linked to the 2030 Agenda for Sustainable Development. The conundrums related to the implementation of SDG policies are for example often co-opted by opponents to vindicate real and imagined grievances and to mobilize public resistance not only against certain SDG policies but also against "the establishment" [6]. One important conundrum is the normativity of sustainability. Because of this, sustainability is criticized as an idea that is dominated by the worldviews, mind-sets and values of the Global North [7-9]. This paper argues that the success of the transformation to sustainability (T2S) depends on the ability to manage the heterogeneity of actors, how they interact or cooperate among each other, how they relate to issues and structures and from which perspective they come from. Power asymmetries define these perspectives as some actors enjoy certain historical privileges while others face additional burdens due to historical structural inequalities. Because of the importance of perspectives, negotiation studies can be valuable not only in analysing how actors can make use of certain resources and of the changes related to T2S to their advantage, but also in developing a "manual" to help them overcome power asymmetries.

The use of analytical frameworks to have a grasp of the elusiveness of transformation to sustainability (T2S) offers insights how sustainability can be achieved despite diversity and what sustainability compels in terms of changes for example in political systems or actors' preferences. Such frameworks aim at providing some structure to manage the complexity of T2S. Section 2 of this paper introduces a negotiation framework to analyse the transformation process towards sustainability. This framework is a theoretical model that does not aim to capture the whole reality nor predict the future. Instead, it professes the actors' perspectives by highlighting the different types of negotiation processes or collective decision-making behind the T2S, identifying the different milestones and the relevant sequencing of policies and actions that can help entrench the relevant sustainability principles by scaling up, down and deep. Section 3 elaborates the different phases of T2S and provides insights how actors can utilize one or many qualities of cooperation (collaboration, coordination, deliberation and orchestration) and master the cognitive games to achieve the relevant milestones. The understanding of the way actors behave as they negotiate the various aspects of sustainability transformation offers insights on how to improve the negotiation capability of individual actors to help them overcome the initial prisoners' dilemma and zero sum characteristic of the transformation system.

At the same time, the theoretical model also addresses some open questions in sustainability studies. Section 4 of the paper elaborates the model by discussing the theoretical and practical lessons drawn from the building up of the model and how the model relates to other questions on T2S. For example, one open question asks when the transformations start, when they end and what happens in between [10,11]. What are the indicators that T2S is advancing and at one point successful? To answer these questions, the theoretical model claims that the T2S is a non-linear and historical transformation process (lessons 1,4) comprised of a collection of both formal and informal agreements that are under certain conditions (e.g., power) actively negotiated by actors through cooperation (lesson 3 ) in various areas, scales and processes (lesson 2) within the T2S. These agreements do not strictly refer to a signed document but can also be tacit or implied without being stated. These collection of agreements indicate the "sustainable new normal" that is both formalized through formal agreements (e.g., coal exit agreement), and institutions (e.g., courts ordering policymakers to do more) and legitimized as reflected by voluntary actions from the public and private sector that are even more ambitious that what were formally agreed upon. The last section concludes by presenting a further research outlook on the applicability of the theoretical model as a benchmark for T2S. 


\section{Background, Methods and Approaches - The Negotiation Framework as a Theoreti- cal Model of Transformation to Sustainability}

Since decades, negotiation scholars have been addressing the question how negotiation as a method of collective decision-making is important to achieve individual sustainability goals before they were even labelled as such. Many negotiation scholars have for example investigated how agreements in climate change mitigation and adaptation [1214], environmental protection [15-17] and public health [18,19] are achieved through negotiations. Generally, these negotiation scholars argue that an excellent understanding of how negotiation occurs in a specific context can help achieve the desired agreements by significantly reducing the transaction costs of collective decision-making. In addition, the deeper understanding of the process can increase the success rate of negotiations by identifying maximizing synergies or co-benefits and resolving trade-offs between issues such as the decoupling of emissions from economic growth. The bundling of multiple interrelated issues can expand the pool of possible negotiation outcomes.

Transformation to sustainability is a concert of various "negotiative" decision-making processes that unfold in multiple levels (e.g., global, regional, national, local), scopes (e.g., state/public or non-state/private), issues (e.g., biodiversity, gender), sectors (e.g., energy, industry), and structures/ frameworks (e.g., United Nations Framework Convention on Climate Change (UNFCCC), the African Union's Agenda 2063) [3,10,20-26]. Each of these levels, etc. involve distinct set of actors, agencies and power relations. A country that for example assumes convening power in the international banking landscape might not be able or even want to seek the same degree of power in setting international norms in human rights or in renewable energy. While the 2030 Agenda for Sustainable Development pushes for the convergence of various sustainability goals [27-29], state and nonstate actors alike will most likely prioritize certain sustainability issues over the others.

At the same time, these levels, etc. are to a certain extent interlinked through synergies, positive and negative externalities, co-benefits and trade-offs. For example, China's decision to reduce emissions might not be solely or primarily driven by the goal to protect the climate but rather by the expected co-benefits such as curbing air pollution [30-32]. This might be unproblematic when the measures taken are complementary, but when priorities are competitive (e.g., climate protection vs. livelihood or decent living), prioritizing for example climate protection at the expense of economic development, some societal groups might radicalize which further increases the hurdles for more ambitious climate policies. Another example is the anticipated decrease in German Official Development Assistance (ODA) for non-climate issues in least developed countries due to geopolitical priorities linked with climate protection) [33]. This might further "(geo) politicize" international development assistance which might further marginalize least or medium developed countries that are not "emitting enough" to gain the attention of German ODA.

This paper argues that the negotiation perspective on T2S can complement the scientific representation of pathways to sustainable futures such as integrated assessment models and scenarios that are often perceived as limited in capturing the heterogeneity within and across actor groups $[34,35]$. Building on previous works of the author of this paper, this paper argues that T2S is a concert of conflicts that can be resolved by focusing on the process of collective decision-making $[3,20,36]$. The developed negotiation framework of T2S (Figure 1) can offer an alternative to integrated assessment model (IAM) paradigm of a single representative agent with economically rational, optimizing decision-making based on perfect foresight and in most cases perfect information [37]. Often colloquially called by negotiation scholars as "scratching someone's back," co-benefits can help promote negotiations, as actors are more willing to accept less optimal solutions in the spirit of compromising if the others are trusted to reciprocate in other issues. Trust and reciprocity are values that most IAMs do not directly address. In climate negotiations, trust between members of the G77+China block play a major role as they share resources to enhance the negotiation leverage of their members in various issues [13]. 
Moreover, the negotiation framework suggests that actors can have multiple interests and therefore advocacies as the T2S unfolds. This plurality within the actor motivates this actor to provide support to other actors negotiating in other issues with the expectation that the success of the others will benefit them directly or indirectly. Therefore, the plurality within the actors enable them to move away from a prisoners' dilemma. In addition, because sustainability issues are intersectional and entail normative objectives, each issue will most likely involve multi-issue activism. For example, a number of studies have found that LGBTQ+ activists are more likely to be involved with environmental activism or racial equality than the rest of the population, because of justice playing a significant in all these issues [38-40]. Moreover, a negotiation outcome, whether a formal agreement (e.g., Paris Agreement) or merely a norm-building understanding (e.g., the 2009 Copenhagen Accord confirming multilateralism as the preferred mechanism of collective climate decision-making), can lay the groundwork for a more ambitious or stringent sustainability policies in the future [3,13].

The negotiation perspective on T2S is an analysis of transformations from the actors' point of view. Because actors adapt to the changing environment, it is inevitable to understand how actors appraise existing structures and make use of their distinct power resources to adjust their strategies and behaviour according to their individual priorities. For example, China's behaviour in various negotiation issues reflects an actor adapting its strategies to the power resources at its disposal. In climate negotiations, China maintains close ties with the G77 alliance, because it acknowledges the burden of isolation and the benefits of cooperation in a multilateral framework [41,42]. At the same time, when increasingly confronted with an existing global trade regime that poses more barriers and unfair norms, China challenges the global trade framework that it sees as dominated by Western countries. As a response, China established the One Belt, One Road Initiative (OBOR), a multilateral regime for regional cooperation and global development where China has the undisputed convening power [43].

In this regard, negotiation studies as presented by the negotiation framework for T2S in this paper can help understand and explain:

1. How achieving one goal such as sustainable mobility can ratchet up (or down) other sustainability goals such as reliable and affordable access to food;

2. How power asymmetries between actors can be managed in the context of common vulnerability and global commons; and

3. How actors' preferences and needs (that may still evolve as the T2S unfolds) can be aligned with sustainability principles to be reflected in any sustainable future as defined by the principle of no one left behind.

Negotiation scholars often use theoretical frameworks to conceptualize the processes how collective decision-making can lead to agreements. By characterizing negotiation as a process that has a temporal start and end, negotiation scholars such as I. William Zartman [44,45], Jacques Rojot [46], Daniel Druckman [47] and William Baber [48] have developed stage and episodic models as analytical frameworks that divide the negotiation process into different phases or segments. The two-stage model of I. William Zartman [45] is comprised of the first three phases aiming to find a general procedure of the negotiation and the fourth and the fifth directly dealing with the details of the implementation of the decisions achieved. Daniel Druckman [47] suggests a six-stage model that starts with getting organised and ends with an agreement on implementing details. With the knowledge of the distinct requirements of each phase, actors can anticipate the milestones to move from one phase to another. These milestones are also referred to as the "turning points" [49] or as "breakpoints" [50]. A full understanding of these milestones allows actors to retrofit their preparations and effectively differentiate their actions, thus, minimizing the costs while maximizing the benefits.

\section{Results: The Phases of the T2S - A Negotiation Framework on the Transformation to Sustainability}


As the following Table 1 synthesizes, the stage or episodic model of negotiation processes is applied to depict the phases of T2S. As illustrated by Table 1, the phases of T2S reflect the phases of a typical negotiation process, such as pre-negotiations (exploratory talks), agenda-setting, clarification of positions, addressing and connecting interests, coming up with solutions and ending the process (with or without an agreement) $[45,46,48]$.

Table 1. The Phases of Transformation to Sustainability (own representation)

\begin{tabular}{|c|c|c|c|c|}
\hline Phases of T2S & $\begin{array}{l}\text { Corresponding } \\
\text { phase(s) in the ne- } \\
\text { gotiation process }\end{array}$ & $\begin{array}{c}\text { Qualities of coopera- } \\
\text { tion }\end{array}$ & Cognitive games & Milestone(s) \\
\hline Entry point & Pre-Negotiation & $\begin{array}{c}\text { Exploration (pre-co- } \\
\text { operation) }\end{array}$ & Ripeness game & $\begin{array}{c}\text { Definition of vision and } \\
\text { priority goals }\end{array}$ \\
\hline Learning & Agenda-Setting & Collaboration & Power game & $\begin{array}{l}\text { Definition of the agenda } \\
\text { and timeline }\end{array}$ \\
\hline Sequencing & $\begin{array}{c}\text { Clarification of posi- } \\
\text { tions }\end{array}$ & $\begin{array}{c}\text { - Collaboration, coor- } \\
\text { dination }\end{array}$ & Bargaining game & $\begin{array}{l}\text { Appraisal of social con- } \\
\text { tract (definition of quality } \\
\text { indicators and scope of ap- } \\
\text { plication through contex- } \\
\text { tualization); rules and pro- } \\
\text { cedures of the bargaining }\end{array}$ \\
\hline Disrupting & $\begin{array}{l}\text { Coming up with the } \\
\text { solutions }\end{array}$ & $\begin{array}{l}\text { Collaboration, coor- } \\
\text { dination, delibera- } \\
\text { tion, orchestration }\end{array}$ & Policy game & $\begin{array}{l}\text { Appraisal of cohesion and } \\
\text { resilience codified in the } \\
\text { social contract } 2.0\end{array}$ \\
\hline Fortifying & Ending the process & $\begin{array}{l}\text { Collaboration, coor- } \\
\text { dination, delibera- } \\
\text { tion, orchestration }\end{array}$ & Scaling game & $\begin{array}{l}\text { Entrenchment of the sus- } \\
\text { tainable new normal (scal- } \\
\text { ing up, out, and deep) }\end{array}$ \\
\hline
\end{tabular}

The table illustrates the integral elements of the T2S. The theoretical model introduces the so-called "qualities" of cooperation to differentiate the relevant sensibilities of cooperation that can be helpful in achieving the corresponding milestone(s) of each phase. These qualities are incremental, which means that a nuance increases in a series of steps [51]. For example, actors are able to orchestrate only if they master collaboration, coordination and deliberation. Another element of the model refers to the cognitive games, which represent the barriers in each phase, if overcome, can help achieve the corresponding milestones. The cognitive games represent the "breaking points" in the T2S through which actors should be reflecting on their strategies and preparations. They serve as reference points to define the context of the problems as well as to fully understand the context and explain the actors' behavioural responses [52,53].

This negotiation framework (Figure 1) is a theoretical model that contemplates on the different phases of the unfolding from the entry point to the envisaged "new sustainable normal" where sustainability principles as reflected by the SDGs are entrenched. The entry point is the critical juncture that opens the T2S when the "ripe moment" has been determined and that there is the initial impression that available resources and conditions can already promise a successful flow of the T2S. 


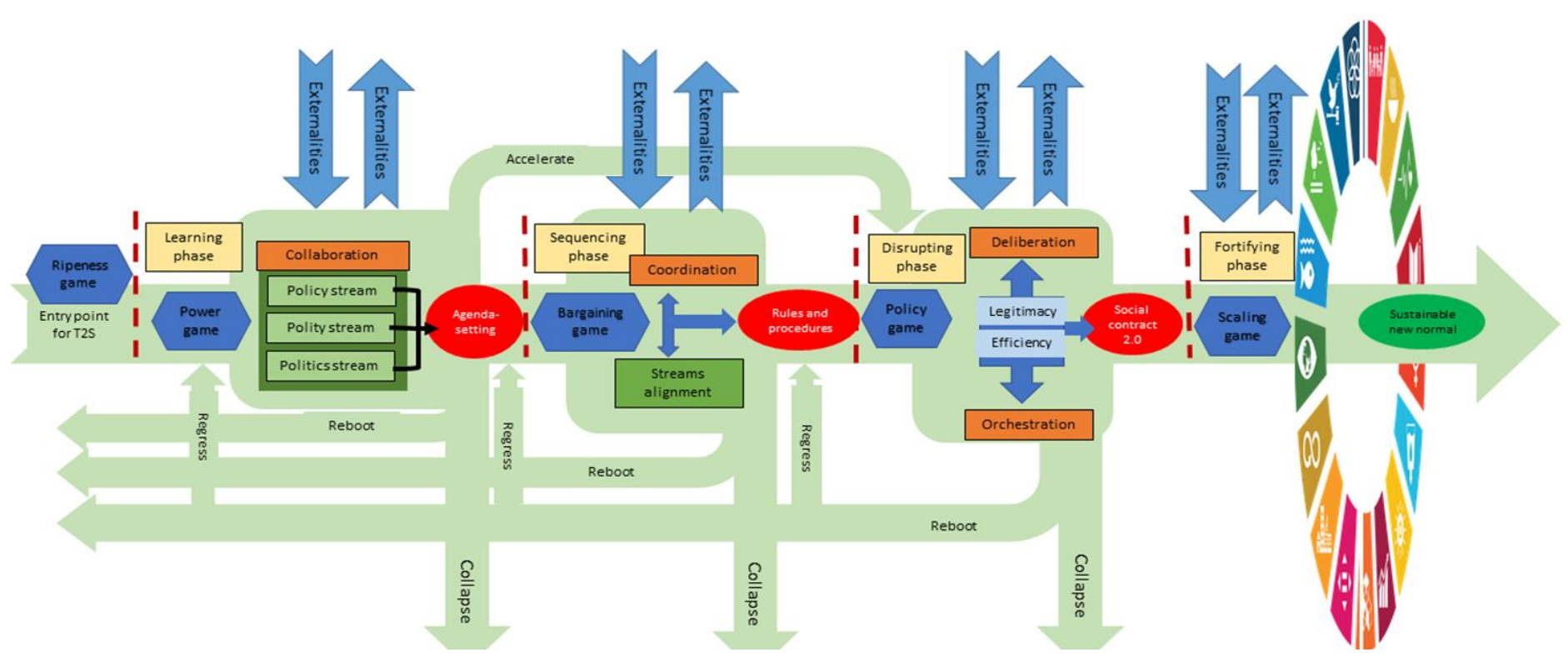

Figure 1. The Phases Model of Transformation to Sustainability - A Negotiation Framework to Capture the Elusiveness of Transformations (own representation)

\subsection{The entry point for T2S as determinant of the "ripe moment" for sustainability transformation}

The theoretical model commences with the entry point, which corresponds to the pre-negotiation stage in negotiation processes. This entry point is the critical juncture where T2S starts if the necessary conditions are present for a specific transformation pathway to be the potentially viable process to achieve sustainability. The following table enumerates these conditions to determine the "ripeness for T2S."

Table 2. "Ripeness for T2S" - Necessary conditions at the entry point

\begin{tabular}{cc}
\hline Conditions & Description \\
\hline Condition 1 & $\begin{array}{c}\text { The conflictual situation defined by common threats and } \\
\text { vulnerabilities arising through unsustainability } \\
\text { Mutually hurting situation arising through non-actions } \\
\text { and disadvantages through non-participation and free- } \\
\text { loading }\end{array}$ \\
Condition 2 & $\begin{array}{c}\text { Conviction of the possibility of resolving common threats } \\
\text { and vulnerabilities through cooperation and negotiation }\end{array}$ \\
\hline
\end{tabular}

The first condition pertains to the occurrence of a conflictual situation that needs to be resolved [54]. The academic debate on sustainability is increasingly connecting human security with climate change, social inequality und unsustainable consumption and production [55-58]. As all humans and social systems are bounded by the same planetary boundaries, all of them are directly or indirected affected by both effects of these boundaries and by the chosen instruments to mitigate or adapt to these effects although in varying degrees, intensities or temporality. These threats and vulnerabilities are on one hand themselves results of or exacerbated by existing structural imbalances and on the other hand creating or fostering further conflicts or inequalities. 
The failure to resolve these conflicts through non-action is met by a situation of "mutually hurting stalemate (MHS)" [59-61]. This MHS implies the absence of free riding and indifference. In T2S, through scientific knowledge, actors expect that the ex-ante costs of early warning, prevention and preparedness are less than the costs of ex-post remediation, repair and restoration [see 62]. At the same time, the current condition of unsustainability poses threats to all actors. The decision not to participate in any solution effort brings further disadvantages. Actors expect that the pay-offs are exclusive only for those who contributed or intended non-participation and free riding are generally linked with unacceptable opportunity costs such as loss of market access, lower yields or loss of competitiveness as well as material damages. In addition, because some actors expect that power asymmetries will change and those "first movers" who for example are able to introduce technological standards and norms will receive additional competitive advantages, other actors are keen on distributing the efforts more broadly among actors.

Furthermore, actors need to be convinced that cooperation and the resulting negotiated agreements are necessary to resolve conflicts notably in cases involving common vulnerabilities where no single actor can effectively resolve the vulnerability [63]. This "Schicksalsgemeinschaft" (community of common fate) as Otto Bauer [64] and Karl Renner [65] once called to depict the process of identity-building, highlights the relevance of negotiations. When addressing global environmental concerns such as climate change, which no single actor can resolve, cooperation becomes an inevitable approach. In addition, explicitly when addressing complex and uncertain phenomena such as sustainable development and climate change, negotiation serves as an apparatus for adaptive learning and for improving social relationships both in the global and domestic level [66,67] . Therefore, this paper argues that a necessary condition to initiate T2S is the conviction that sustainability goals can only be achieved through cooperation reflected in the different levels, formats and structures of negotiations [3,21].

Timing is a concept that is central to negotiation studies, which is similarly important to scholarly studies of transformations and sustainability. Relevant actors, both those who prefer to resist changes ("why change when it has worked for decades), those who propagate changes ("the shoes are already too small") and those who are indifferent or oblivious ("whatever is fine"), will at one point find themselves in a pre-negotiation (or pretransformation) stage deciding whether T2S is what is needed to resolve the MHS. In this stage, those actors for change will attempt to persuade those who prefer to maintain the status quo by pointing out why inaction is also hurting them. It is important to note that these "status quo actors" resist change for various reasons. Some might reject T2S because the unpredictability or uncertainty of it might bring them into a disadvantageous position in the future. Others might resist change merely because of the lack of information or that they have based their judgment on wrong or incomplete information. These actors should not however be "demonized" but rather be given the resources to help them overcome their prisoners' dilemma [68,69]. From the negotiation perspective, initiating T2S is a question of identifying where it hurts and how to resolve information asymmetries and to include all actors as part of the solution. In other words, finding entry points to T2S refers to the fostering of the "ripeness" for sustainability.

The idea of the "ripe moment" for T2S as derived from negotiation theory is a question of perception of discomfort and of the anticipation that what can be achieved through the T2S outweighs the anticipated benefits of non-action or non-participation for the status quo actors. The perception of discomfort grounded in cost-benefit analysis defines a "mutually hurting stalemate" (MHS) for all parties, even to those who are indifferent to T2S. The concept of MHS is the notion of increasing pain associated with the present (conflictual) course. When the parties find themselves locked in a conflict from which they cannot escalate to victory and this deadlock is painful to both of them (although not necessary in equal degree or for the same reasons), they are "ripe" or ready to negotiate $[70,71]$. 
Applying this ripeness concept to T2S, both status quo and change actors are in an impasse, which is hurting all actors in various degrees or for various reasons. For example, actors from the fossil fuel sectors can find the uncertainty and unpredictability in climate policy making tiresome or the "public shaming" unbearable that they recognize that it is better for them to adapt, compromise and engage in finding concrete solutions rather than boycotting any policy consultation whose outcome will eventually affect them. Joining the "sustainability bandwagon" becomes the more preferable action, because they can maintain control or can even gain public support for example when they show that they have already been contributing to the achievement of the 2030 Agenda. For example, when mapping the sustainability efforts of polluting industry sectors in Brazil, Vera Thorstensen et al. [72] found out that several actors in the oil, natural gas, steel or cement sectors have already implemented voluntary sustainability standards (VSS) and other forms of environmental due diligence. Some of the implemented VSS are even more ambitious compared to other sectors or to state regulations in order for them to meet their own priorities such as reduction of energy costs or ensuring reliable value chains.

The "ripe moment" is only a condition, necessary but not sufficient for the initiation and the success of negotiations. In the same manner, the "ripe moment" does not always lead to the initiation of T2S nor can it guarantee that the transformation process will be successful especially when the actors for example lack the necessary resources for them to survive shocks linked to certain disruptions that the T2S entails. Therefore, the ripe moment needs to be complemented by the positive outlook that the institutions and governance modes exist for the actors to fulfil the tasks and achieve the different milestones for each phase or stage of the transformation process.

\subsection{The learning phase, the power game, and the collaboration between the three streams}

The first phase pertains to the "learning phase" where the actors from the three streams learn the first challenge of the T2S - the power game. The first process-related challenges are most likely to arise as they collaborate with their counterparts to set up the agenda items for subsequent deeper discussions. The theoretical models argues that the perception of power dictates the intention or ability to reciprocate concessions. Mastering the power game depends on moving from a zero sum to a positive sum relationships. When the actors, irrespective of their classification to a stream, are able to adapt to the power game, then power becomes less a driver of the prisoners' dilemma but more of collaboration.

The actors are generally classified into one of the three streams (policy, polity and politics), which shed light to the sources of power (e.g., convening power, procedural power, inconvenience power) [73]. Figure 1 pinpoints these streams as policy, polity, and politics streams and modifies the multiple streams framework of John Kingdon in assessing public policy and governance [74]. These streams are in the theoretical model classifications of actors according to their role in public policy and implies that the theoretical model also assumes a broader definition of governance [21,75-77].

The policy stream refers to actors that are directly involved in designing, evaluating, and implementing policies. They identify emerging risks and threats, design, and implement policy instruments to resolve these problems within the boundaries given to them by their constituents and since recently also by planetary boundaries [78,79]. At the same time, these boundaries imply the need for some degree of accountability, as the other two streams evaluate and legitimise the policies. These policy instruments include regulation, incentives or penalties that aim to stir certain responses from target groups such as economic actors and private households [10,80,81].

Nevertheless, the policy stream is itself heterogeneous with actors often motivated by a variety of political ideologies that can define their preferences to deploy certain policy 
instruments over the others. Hence, competition within the policy stream is to be expected, if not desired, and effective communication with the society-at-large becomes inevitable for political survival. In addition, to foster both legitimacy and maturation of policies, the policy stream is in constant exchange with the other streams including policy entrepreneurs, such as think tanks, scientific communities, NGOs as well as business and industry groups, to improve policy development and implementation [82].

The polity stream pertains to formal institutions (e.g., constitutional court) and other bureaucratic arrangements (e.g., federalism) that facilitate various types of verification and compliance in policymaking. In other words, the polity stream serves as "check and balance" for both the policy and politics stream. The polity stream includes institutions and agents that monitor, evaluate, verify or sanction government actions and legislation $[83,84]$. These institutions are above policies and politics to ensure social cohesion and continuity. For example, a government may initiate new policies to upgrade the country's energy supply system by expanding the deployment of renewable energy technologies. However, the implementation of these policies will need to adhere, for instance, to existing constitutional limitations as well as depending on the legal culture on precedents. In addition, these institutions can also initiate impulses for new policies or exercise constraints or provide support to impulses from both state and non-state actors. For example, the Federal Court in Australia declared that the Minister for the Environment owes a duty of care to Australian children who would suffer potential "catastrophic harm" from the climate change implications of approving an extension to a coal mine [85].

The politics stream consists of "highly motivated individuals" and non-state actors that advocate the interests of their constituents. The mandate they receive from their constituents include drawing attention to policy problems, identify gaps in governance (e.g., public-private partnerships), provide specialized technical knowledge, build coalitions of support or opposition, democratize policy making processes, deliver scalable solutions, and stimulate further societal and legislative actions [82,86,87]. In T2S, the politics stream depends on networks to complement state agencies and institutions. They maintain close and long-term partnership not only with proximate policymakers but also with other nonstate actors to build a network of state and non-state actors (policy silos) [21]. For example, the Fridays for Future movement has been successful in creating a policy silos in climate protection by mobilizing public support and pressuring policymakers for more stringent climate protection measures not only through rhetoric but also by building a broader coalition of supporters such as the Churches for Future and the Scientists for Future [88,89]. In addition, the politics stream is a major driver of policy diffusion by creating pulling effects that bring various policy silos together through which the effectiveness of policies is improved. For example, the policy stream can provide specialised knowledge that can help translate green energy technological innovation into social or cultural innovation. By connecting for example energy storage innovation with climate and welfare policies this specific technological innovation translates into social or cultural innovation that will lead to its "deep" scaling in the fortifying phase of T2S [90-92].

Corresponding to the agenda setting of the negotiation process, this learning phase of the T2S needs to come into terms with the power game and the related existing power structures to lay the groundwork for the constitution of the "rules and procedures" in the next phase. The power game refers to how actors adapt their goals and strategies to address related issues such as power asymmetry. The power game explains how power relations can limit the set of potential actions or draw a specific response from counterparts. When weaker actors recognize that the most powerful actors cannot subjugate the others without hurting themselves, the probability of them collaborating becomes higher. Power is therefore a variable that allows the assessment or, to a distinct degree, the predictability of actions. This predictability of actions allows for adequate preparations and development of strategies in order to adapt to power realities. In this case, weaker actors can, for instance, maximize the leverage potentials of their resources through strategic placement 
and timing to achieve the best possible outcome [93]. For example, G77 countries prefer a multilateral setting in climate negotiations, because it enables bundling and coupling of leverage vis-à-vis developed countries [13].

Another strategy to deal with power asymmetry under zero-sum is by confirming common vulnerabilities and shared costs. Common problems that require participation from all actors irrespective of their level of power, resolves the prisoners' dilemma. At the same time, in fewer cases where power still matters, weaker actors are for example able to adapt their strategies (e.g., coalition building, issue bundling, sending their best representatives) to achieve their goals [93]. By mastering the "power game," actors are able to adapt their strategies and effectively participate in forging the formal agenda in the learning phase, which once achieved allows the process to come to the next phase.

\subsection{The sequencing phase and the bargaining game for rule-based transformation}

The sequencing phase of T2S witnesses the alignment of streams, that is, the convergence of norms and values resulting through the bargaining game between actors from the three streams. This streams alignment is important for cooperation, because it allows reciprocity and building up of a we-identity [94,95]. In addition, streams alignment allows the completion of policy cycles (development, evaluation, legitimisation and implementation) that advance the T2S. The streams align because each of them offers important puzzle parts of the solution as they complement and compete with each other. In this phase, the interactions among the policy, polity, and politics streams generate new norms or standards and other de facto "shared realities" that constitute the new rules of the bargaining game. For example, as these streams align, their understanding of what the problem is all about can be standardised and at the point, they will speak the same language, use the same indicators and even exchange personnel between streams (e.g., environmental activist seeking election). This enhanced understanding facilitates the communication and persuasion efforts between actors, thus, mastering the bargaining game, which refers to the persuasion ability of actors.

The sequencing phase commences once the three streams are able to agree on the agenda and timeframe of the T2S during the learning phase. The envisaged milestone in this phase is the establishment of the rules and procedures of the T2S within the boundaries of the negotiated "tolerable window" [96,97]. For example, the tolerable window for the policies advancing the German Energiewende is oriented towards the principles of a soziale Marktwirtschaft (social market economy) that combines liberal economic and welfare policies [98,99]. The political framework for the Energiewende foresees minimal government intervention while ensuring the consequent stable income of private households. This window represents the current social contract that needs to be regularly consulted with the society-at-large and if needed revised to support the T2S. A social contract "contends a culture of attentiveness, (...) a culture of participation, (...) and a culture of obligation towards future generations" [100] (p.2). The tolerable window represents a confidence building mechanism that assures reciprocity and the guarantee that potential burdens will remain tolerable through thresholds and compensations. With the achievement of the agenda as the milestone of the previous phase, the actors belonging to the three streams are able to cope with the prisoners' dilemma at the T2S, because this milestone gives them an overview for example on potential coalition or network partners. With an overview over the agenda, the policy stream can limit the extent of its coordination efforts, focus on leverage points (actions that represent the minimum costs but with the maximum effects), and equitably distribute the costs and burden of the T2S among themselves.

Moreover, the setting of the agenda paves way for substantial preparations to make their case in front of the other actors. Looking at Germany's Energiewende, the federal government developed the framework of the energy transition by identifying the four major agenda of the Energiewende: 1) Phase out of nuclear energy by 2022; (2)increase of 
share of renewables in electricity generation; (3) liberalization and infrastructure improvement in its energy supply system; and (4) increase of energy efficiency by reducing primary energy consumption particularly of the transport sector [101,102]. Upon agreement on these four agenda items, most German ministries such as the Federal Ministry for Economic Affairs and Energy (BMWi) and the Federal Ministry for the Environment, Nature Conservation and Nuclear Safety (BMU) as well as the governments of the 16 German states (Bundesländer) have developed their own positions on certain themes and implementation goals and strategies. At the same time, they launched their own technical research to find scientific evidence that can support their positions [103]. In addition, those affected sectors from the politics stream such as energy, transportation and industry sectors have mobilized their constituents and networks to seek popular support for their proposals to implement the four major agenda [104].

In the sequencing phase, the actors from all streams launch series of coordination efforts first within their networks within their stream and second with network members from the other streams. At this point, some actors from both the policy and politics streams, especially those belonging to the opposition party or affected sectors, will already seek intervention from the polity stream to clarify constitutional or judicial constraints. At the same time, members from the polity stream can be proactive in arbitrating between actors (both among actors from the same stream or between the streams). In the German Energiewende, legal institutions have become heavily involved as several affected groups launched thousands of legal challenges against the Energiewende [105,106]. Through thousands of legal challenges especially at the beginning of the transition, new laws and regulations or additional scientific research were established to close these gaps in legislation and research. For example, immediately after the German Bundestag approved the legislative framework, additional funding was released to understand more the effects of the accelerated deployment of renewable energy in Germany. The Federal Ministry of Food and Agriculture (BMEL) launched its 50 million Euro R\&D program to study the connection between food production and the use of biomass energy [99].

By coordinating, streams are aligned as actors appraise the status quo, evaluate existing rules, assess precedents, and improve their understanding of where they are coming from. The mastering of the bargaining game ensures effective alignment of interests and resources. For example, government ministries coordinate to combine resources and to ensure the coherence of their policies. Actors from the politics stream are able to review the compatibility of their positions with those of the other network members, because there are already well-established communication channels within the network. Hence, networks facilitate the bargaining game. At the same time, the alignment implies that they have found mutually acceptable procedures on how to elaborate the technical aspects of the measures that are to be implemented. At this point, the focus of the interactions will start to shift from the procedure of interactions towards the material content of transformation.

\subsection{The disrupting phase and the policy game to connect solutions with identities}

The disrupting phase starts after the achievement of a formal acceptance of the rules and procedures on bargaining that allows a "rules based" elaboration of the technical solutions to address the barriers to behavioural change. With this milestone, the policy game becomes the driver of cooperation, that is, of deliberation, where actors connect their worldviews with the technical aspects of the presented measures, and of orchestration where actors link the sum of their worldviews and technical aspects to those of their counterparts from other sectors or scales. In this stage, the actors reflect on the compatibility of technical solutions with their identities and if new problem issues or concerns arise, then they are able to communicate this to the others. In this stage, some actors might experience a turnaround from their previous positions. For example, German energy utilities eventually gave up their opposition to the Energiewende. As the rules based framework of the 
transition was established, provisions were reached to adequately compensate for their loss (e.g., 90 billion Euro for the coal sector and affected communities). In addition, they are given reasonable flexibility to ensure economic competitiveness (e.g., exemption from the renewable energy surcharge, and that the Energiewende even promises new opportunities, they gave up their resistance $[107,108]$.

The policy game is the most important cognitive barrier in this phase. It refers to the efforts to effectively implement and legitimise the policies and actions needed to make T2S positive sum. With this, the actors define the scope and normative limitations of the negotiated measures according to how they understand the mandate given to them by their constituents. This mandate is most likely fulfilled when the technical measures are effective to achieve the goals. This phase is disruptive not only from a technological point of view, but also from the point of view of behavioural change. On one hand, new solutions will disrupt for example existing carbon lock-ins as new technologies and methods are introduced to break path dependencies. On the other hand, by mastering the bargaining game, actors know how to persuade the others and they learned how to be persuaded with integrity. As such, they can now be persuaded and motivated to change their initial reservations or backtrack from their initial support to non-sustainable measures such as subsidies to fossil fuel energy. At the same time, the art and science of persuasion can disrupt existing coalitions or networks of recalcitrant actors. As actors deliberate and orchestrate, they will most likely find new indicators of efficiency and legitimacy that will provide new elements to the new social contract. The disrupting phase ends with the achievement of a new social contract (2.0) which sums up the deliberated and orchestrated rules and procedures of the sustainable new normal.

At this point of the transformation process, boycott efforts and spoiling strategies of status quo agents are no longer viable as the stakes of non-cooperation are already too high to tolerate due to new lock-ins and standards established by change agents. Once public opinion has shifted, status quo or recalcitrant agents now acknowledge that transformational change is imminent and if they want to maintain relevance and certain privileges then they need to influence the design of new institutions and structures. For example, several years ago, many lobby groups representing the German car industry were spending millions of Euros to challenge attempts to mitigate GHG emissions (Laville 2019). Eventually, the car industry accepted that the public opinion has shifted and it started to diversify or even change its rhetoric and started aligning its business models towards sustainability goals. In addition, status quo agents may recognize the practicability of revising their political and social mandate if they want to stay system relevant.

In this phase of the transformation, the specificities of the new normal are codified in the new social contract. These specificities are outcomes of discourses in varying scales and dimensions as well as in different knowledge and policy domains. Bargaining and policy games have become interconnected. This means that policies are now direct outcomes of bargaining between streams as opposed to policies reached in closed doors by single ministries and with less or no public consultation [109-111]. Bottom-up processes in governance are no longer the exemption but the rule. Discourses unfold at the cognitive level primarily to develop transformative narratives [112,113]. These narratives are important elements of the rhetorical structure that can help not only elevate specific problem issues from low politics into high politics but also assess the sustainability transformation pathways being taken [114]. Narratives construe the reality to which actions are reacting. In the context of transformation to sustainability, narratives define which pathways are consistent with the principles of sustainability. In cases of deviations, these narratives can help the process to get back into track.

\subsection{The fortifying phase and the scaling game to close the T2S process}

Ending transformations remains a huge challenge for academic research. One reason is that initially regarded as successful empirical cases on transformations can still regress 
which casts doubt on the usefulness of current methods to measure and evaluate the success of policies implemented. For example, at the beginning of the 2000s, economies in transitions such as Hungary and Poland were ranked by the Bertelsmann Transformation Index (BTI) as the countries that ranked as most successful in their transformation processes toward democracy and a market economy. Twenty years later, both of them plunged in the ranking and are now classified by BTI as "defective democracy" after defects in democracy "have persisted and have become even more entrenched (...)" $[115,116]$.

Another challenge is that systems are constantly evolving and completed transitions are still subjected to further shifts that can still reverse past-entrenched norms and practices. The temporal aspect of transformations can be fuzzy because of uncertainty about the length of time a process needs to be completed. For example, Elisabetta de Giorgi [117] sees the "never-ending transformation" of the Italian party system as the consequence of various phases in the history of the Italian party system that are usually started and ended by a major political crisis. While she confirms the assumptions made by the Copenhagen School and by this theoretical model about the importance of crises in driving transformations, she also pinpoints the need to understand why transformations cease to close.

The theoretical model assumes that the fortifying phase can close the transformation where the sustainable new normal is achieved through the scaling game. In this model, the scaling game refers to the efforts to replace non-sustainable (carbon) lock-ins and entrench sustainability principles in the way that they become self-enforcing and deeply embedded in institutions, cultures and behaviour that are oriented towards sustainability $[118,119]$. Non-sustainable (carbon) lock-ins can frustrate change agents or even destroy political will as well increase the costs of change $[119,120]$. These carbon lock-ins can be classified as governance-related, institutional, infrastructural, technological, and behavioural [118] (p. 8-12). At the same time, replacing non-sustainable lock-ins with sustainable lock-ins assume that societies do need lock-ins in form of norms, as they provide benchmarks for "appropriate" behaviour [118,121,122]. Moreover, entrenchment means that deviations to sustainability are sanctioned, because they are perceived as irrational (in terms of cost vs. benefits) and makes one "unfit" for survival.

The previous stage shifts to the fourth and last stage when old lock-ins have been uprooted and new ones established, which are conducive to sustainability. In this fortifying phase, the sustainability principles and the chosen approaches are entrenched, that is, now codified in the new social contract 2.0. This entrenchment means the successful threefold scaling of sustainability principles, which corresponds to the typologies of routes to systemic impact introduced by Darcy Riddel and Michele-Lee Moore [123]:

1. Scaling up (changes in institutions at the level of policy, rules, and laws);

2. Scaling out (replication and dissemination, increasing the number of the extent of impacted people and communities); and

3. Scaling deep (changing relationships, cultural values, belief, and world views).

The three scaling of sustainability that constitutes the concept of entrenchment in this theoretical model of the T2S can be elaborated through the example of the German Energiewende. While the Energiewende is still in progress, there are already discussions on how its closure can determined. The Stiftung Energie \& Klimaschutz conducted a survey asking respondents when they deem the energy transition as completed [124]. About $62 \%$ of the respondents see the Energiewende as completed when all its predetermined targets and measures have been reached. The remaining respondents already see it as completed when at least one of the goals has been reached with $19 \%$ already attributing completion when at least $80 \%$ of the energy mix is from renewable energy (without nuclear). However, it was not clear whether the respondents would prefer that these targets were reached within the given timeframe. Another open question is whether the respondents 
would already classify the Energiewende as failed if the timeframe was not followed. This theoretical model, however, argues that the completion of the Energiewende goes beyond the achievement of the concrete targets and measures as the threefold scaling of sustainability principles suggests.

\subsubsection{Scaling up - the Energiewende as a mechanism of rewards and sanctions}

Scaling up of the T2S depicts impacting law and policy. As Michele-Lee Moore et al. [123] explain, scaling up is based on the recognition that the roots of the problems (threats and risks) can only be properly resolved when innovative approaches for example to achieve sustainability are codified in law, policy and institutions. This scaling up can be regarded as the most obvious indicator of closure of transformation processes, because there are quantitative and qualitative indicators that can show whether new laws and policies were introduced, through which the concrete targets and measures were or could be achieved. Therefore, the policy and polity streams are in T2S both responsible for scaling up of sustainability by reflecting on the internal changes that they have experienced following the establishment of new laws and policies.

The scaling up of sustainability principles in the German Energiewende is still a work in progress. New laws and policies are regularly introduced as part of the strategic political and legal framework for the Energiewende. Examples include the Electricty Market 2.0 to enable the electricity market suitable to accommodate growing shares of renewable energy or the National Action Plan on Energy Efficiency (NAPE) of 2014 to provide consumers with information and advice on energy efficiency. There are already some indicators that the German legislative and political framework for the Energiewende is already able to mobilize a critical mass of action not only from the politics stream but also from the society-at-large. This corresponds to the catalytic cooperation model introduced by Thomas Hale [125] where "catalytic institutions" motivate shifts in the actors' preferences by encouraging first-movers (change agents) to come forward, punishing spoilers and encouraging small steps even from recalcitrant actors (status quo agents). For example, high levels of the German public funding for research and investment into renewable energy complements the existing political framework for the Energiewende. In 2019, there was only Euro 19.6 million public funding for research into fossil fuels compared to Euro 245.6 million and Euro 206.7 million into renewable energy and energy efficiency respectively. In addition, public investment in clean energy in 2019 was more than Euro 4 billion [126]. This high level of public funding in research and public investment encourages not only technological innovation but also behavioural change.

As Table A1 (supplementary material in the appendix) shows, Germany is on track to achieve some of the concrete targets and measures of the Energiewende. The other targets and measures with pessimistic outlooks are still expected to be possible if more stringent climate protection and energy efficiency (especially in the transport sector) policies are introduced [127]. The target to phase out nuclear energy by 2022 is expected to be reached after the federal government agreed to pay Euro 2.3 billion as compensation to nuclear power plant owners and operators ensuring that the last two remaining nuclear power plants to be closed by December 2022 [128]. This payment is itself a measure to encourage concessions from recalcitrant actors from the energy sector. Another scaling up in the German Energiewende pertains to the emergence of policy mixes that couple for example the costs of heating and transport with the costs of CO2 [99]. The country's national emissions trading system for fuels scales up the Energiewende by creating more incentive for emission reduction from the heating and transport sectors.

3.5.2 Scaling out - the Energiewende as principle for foreign policy and international cooperation \& development 
The scaling out of the Energiewende is manifested by the replication of innovations in different communities with the intention to achieve similar results [123]. In the theoretical model, all streams can serve as the main driver of scaling out. There are some indicators that the scaling out of the Energiewende is already in progress. As the idea of sustainable transitions in other sectors has gained momentum partly due to the reaching of some of the goals of the Energiewende. Examples include the Mobilitäts-/ Verkehrswende (mobility/transport transition) $[129,130]$ and Agrarwende (transition in the agricultural sector) [131]. Change actors in other sectors other than the energy sector have gained confidence through the positive experiences from the Energiewende as they discover for example new arguments to rebut sociotechnical narratives (e.g., loss of jobs, relocation of companies) effectively used by recalcitrant or status quo agents to resist changes [127,132].

Another indicator of the scaling out of the Energiewende is its integration both in Germany's foreign and international development policies. Some experts and German politicians suggest that the Energiewende can be an "export hit" to other countries $[133,134]$. The reform strategy "BMZ 2030" implemented by the German Federal Ministry for Economic Cooperation and Development (BMZ) incorporates some elements and positive experiences from the Energiewende [135]. The reform strategy aims at improving how Germany conducts partnership with developing countries within its understanding of its convening power (Gestaltungsmacht). It identifies "green people's energy" as one of the ten initiative areas that places a special development policy focus on energy transition in partner countries [136]. Because of the inclusion of energy as an initiative area, the bilateral development partnerships between Germany and many partner countries have been mandated to focus more on energy transition in the context of climate protection and energy security in partner countries. Examples of these partnerships include the KoreanGerman Energy Partnership's Energy Transition working group, the German-New Zealand hydrogen partnership, and the EnerPhil project with the Philippines. Many German embassies are now actively initiating and coordinating local networks on energy transition in their host countries while bringing in German energy experts to share good practices from the German Energiewende [137].

\subsubsection{Scaling deep - the Energiewende as driver of shared realities in communities}

The scaling deep is manifested by the attainment of "big cultural ideas," by using stories or narratives to shift norms and beliefs and by investing in transformative learning and communities of practice [123]. In other words, scaling deep of the T2S means that sociotechnical narratives about the benefits and urgency of the sustainable practices have become mainstreamed in a way that they are taken as self-evident and self-enforcing. In addition, scaling deep can be monitored and measured through the quantity and quality of knowledge diplomacy and knowledge networks through which different actors question existing narratives and if needed create new ones, exchange perspectives, adjust their preferences, activities and behaviour in order to obtain benefits often in the form of increased knowledge [138,139].

Expanding the idea of scaling deep, this paper argues that T2S requires the ability of the system to survive stress tests caused by endogenous and exogenous shocks and disruptions. Scaling deep can also be characterized as the resilience of the system to thwart disruptive backlashes and paradoxes $[21,140,141]$. To achieve scaling deep, this paper contends that for the social system to achieve resilience as T2S unfolds, the society-at-large should still maintain: (1) the same cooperative relationship between populations, (2) the identity markers that connect people, (3) the ability of communities to communicate and negotiate with their environment, (4) the ability to allocate scarce resources efficiently, (5) the desired ecosystem services, (6) the specific relationships between interacting species, and (7) the essential structures of natural capital [21,142-145]. 
The politics stream is the primary driver of the scaling deep of the Energiewende. The scaling deep profits from the reinvigorated and exponential growth in German scientific research on climate protection, renewable energy and energy efficiency that started at the end of the 20th century. The increasing volume of public funding for research into green energy and energy efficiency as well as into climate protection indicates investing in transformative learning and mobilising communities of practice. The establishment of several new centres of excellence in sustainability, sustainable energy and climate protection in German universities and institutions of higher learning has supported both change and recalcitrant actors from all streams to rely on reference materials for knowledge to further mobilize efforts to elevate climate protection and green energy as a political agenda [146]. Knowledge networks such as the German Scientific Platform for the 2030 Agenda, the German Sustainable Development Solutions Network (SDSN), and the increased inclusion of scientific bodies in constituting sustainability policies in Germany are other indicators of scaling deep of the Energiewende as they help connect the energy transition to the larger sustainability context in the country [22]. Moreover, the transformative learning occurring in all communities and sectors helps converge perspectives on sustainability and support commitment to the relationships developed.

To conclude, the types of scaling represent routes to systematic impacts and insinuate the mainstreaming of exceptionalist and emergency measures in a way that the new sustainability-inclined path dependencies will define the set of future decisions and policies. Nevertheless, the fortifying phase does not mean the permanent closure of the T2S as new information or new events might still warrant minor revisions in the social mandate or mobilize new niche groups that challenge the outcomes of the T2S. Paradoxically, successfully negotiated outcomes leading to the entrenchment of sustainability and hence the sustainable new normal will highly depend on channels to re-negotiate some rules and procedures without questioning the legitimacy of the outcome. Resilience is only possible when the system is able to grow.

\section{Discussion of the lessons from the Negotiation Framework - Understanding and Explaining Transformation to Sustainability}

This section elaborates the lessons from the theoretical model. These lessons are linked to the underlying assumptions made to fully understand and explain how this model relates to sustainability (as a normative goal) and to transformation (as a process). Analysing the T2S as a concert of phases enables a sharper distinction between the different interactions and behaviours of actors and therefore the possibility of more fine-tuned approaches. As elaborated in the next subsections, each phase demands a distinct set of (power) resources and strategies and therefore warrants a distinct set of analysis.

Lesson 1. Trajectories of sustainable development or pathways of sustainability are transformation processes.

Important to this model is its assumption on the concept of sustainable development. Hopwood et al. [2] acknowledge the different meanings and therefore different responses to the concept of sustainable development. Their classification and mapping of different schools of sustainable develop allows a clear positioning for this paper. Some academic scholars and civil society groups argue that sustainability can be achieved within the present structures [147-149] and/or that fundamental reform is necessary but without a full rupture with the existing arrangements $[150,151]$. However, this paper follows the "transformationists" in arguing that "correcting" the roots of unsustainable practices (e.g., carbon lock-ins, inequality, power imbalances, and inept governance) through deep transformation is a precondition to sustainability [152-155]. For them, the current dominance of several "unsustainable" paradigms (and the related narratives that legitimize them) is deeply embedded into the social, institutional, political, cultural, and economic fabric of 
global societies. Against this backdrop, achieving a sustainable future requires the rethinking of existing concepts such as economic growth and "repairing" of various human relationships [3,90,156,157].

This theoretical model adopts a transformatory approach that connects human relationships with environmental questions [94,154,158,159]. This approach understands a strong commitment to social equity and environmental integrity where there is no exploitation of people for example of women and indigenous communities and the environment by a small minority but powerful people [160-163].

Lesson 2. Transformation to sustainability is a "nuanced transformation" where worldviews and scales converge

Transformation to sustainability witness the convergence of various worldviews and scales. While this paper makes a case for deep transformation, it also argues that transformation does not need to be always radical and disruptive in all aspects nor is transformation to sustainability a $100 \%$ renunciation of the status quo. Some "unsustainable" practices can be tolerated within limits or when they constitute some positive aspects of the current system that should be preserved especially those that help maintain identities and communities. The decision of which of these practices are to be preserved and which to abolish should be an outcome of a public debate. One example of these is the role of monarchies in democratic systems. For some (constitutional) monarchies are expressions of inequality and non-democratic ideas that are not compatible with sustainability $[164,165]$, for others these institutions are part of identities that should be preserved. For example, Phillip Blond argues through his concept of the "red Tory" that in the context of the United Kingdom the monarchy has "important, continuing and foundational role in contemporary British politics" which paradoxically can hold elected politics and democratic politics to a higher standard [166].

Instead of uncontrolled deep transformation, this paper highlights the possibility of "nuanced transformation" and emphasizes the need to focus on leverage points. Hannah Marlen Lübker et al. [152], Donella Meadows [167] and Joern Fischer \& Maraja Riechers [168] draw on the leverage point perspective, that while a paradigm shift - a socially shared profound change - is a precondition for any sustainability transformation, relatively minor interventions in the so-called "leverage points" can already lead to relatively major changes in certain outcomes. Focusing on leverage points allow a "nuanced" deep transformation process that minimizes the costs of change and the loss of identities and communities. For example, a nuanced sustainable energy transformation may for example first target (consumer's) behavioural change through incentives if this will most likely lead to the desired paradigm shift. In an earlier work, the author of this paper argues that a transformation process is likely initiated when members of the society experience at least one symptom of "cognitive vulnerability" (disengagement, disidentification, disenchantment and disorientation) [3]. If the social system lacks the ability to absorb shocks resulting from these cognitive vulnerabilities through some welfare mechanisms, the uncertainty and vacuums (and the related justification of violence), resulting from these cognitive vulnerabilities can lead to more immaterial damage that might require intolerable additional costs to repair or can even lead to total system collapse. By looking at the different phases of T2S, the potential leverage points for nuanced transformations can be identified to minimize disruptions and cognitive vulnerabilities.

Another important characteristic of nuanced transformation is its scaling diversity. This refers to the different scales of T2S. This paper defines scales as the "space" where sustainability initiatives are designed, implemented, legitimized, evaluated and modified. David Lam et al. [1] have defined sustainability initiatives as projects, products, practices, approaches, technologies or policy instruments that pose potential solutions to sustaina- 
bility problems. The presented theoretical model depicts each scale as an analytical framework that can refer to space (global, regional, national and local levels) and sectoral issues (energy, transport), to power relations (e.g., centre vs. periphery) as well a combination of these three. For example, one T2S model can look at Germany's (space) energy transition (issue/sector) or the transformation process of the coal-dependent peripheral region of Lausitz. While these scales can influence each other, each scale has its distinct set of sustainability initiatives that bring together certain actors, issues, institutions and governance structures. For example, a T2S scale that is focusing on social innovations will most likely have different power structures than a T2S scale that focuses on technological transformations $[10,123]$. These different scales can complement, reinforce or compete with each other, reflecting the possible trade-offs, co-benefits, and synergies between sustainability goals. The scales can also be regarded as interactive puzzle parts that require careful sequencing and orchestrating. One important leverage point refers to this scaling diversity. For example, focusing on policy mixes can minimize shocks, because the risks are distributed among more actors or public acceptance is fostered [28].

Lesson 3. The "best possible behaviour" is cooperation between actors.

Another major lesson pertains to the nature, role and drivers of cooperation in the T2S. The academic literature is rich in conceptualizing cooperation. An early stance on cooperation is linked with the inclusive fitness theory that highlights the Darwinian or natural selection context of cooperation whereas living beings cooperate to survive. People tend to select those cooperation partners who offer success [169-171]. This stance implies what Robert Trivers [172] call the "reciprocal altruism" in which people cooperate if they see it as mutually beneficial. The genetic kinship theory of William Hamilton [169] highlights the importance of self-interest in cooperation which inevitably elevates the meaning of reciprocity in the decision whether to cooperate or not. Closely related to this Machiavellian stance on cooperation refers to the mathematical perspectives on human behaviour, which are supported by game theorists [173,174]. Robert Axelrod [171] argues against the background of game theory, the biggest pay-off for an individual under the zero sum conditions of the prisoners dilemma is not to cooperate. However, because real life is not zero sum and that people can learn about the intentions of the others, cooperation ("be nice") promises the biggest pay-off [175,176].

In negotiation studies, there is a huge debate whether actors are rationally behaving as they seek the best possible outcome even at the expense of the others $[177,178]$. The rationality of actors is also an subject of debate in transformation and sustainability studies [see 179,180]. This theoretical model focuses on the trade-offs between the efficiency of (policy) goals and the goal of promoting participation in forging and implementing these goals. In this regard, the "best possible behaviour" of the actors is oriented towards the balance of achieving efficiency on one hand and maintaining legitimacy on the other hand [3] (p. 51).

In this theoretical model, the "best possible behaviour" drives cooperation between actors. Therefore, as aligned with Dirk Messner's [95] arguments, while actors involved in the T2S will reflect upon the payoffs of engagement or cooperation given the existing power asymmetries, the decision to be part of the T2S goes beyond the assumptions of rational choice and narrow self-interest. Non-cooperation becomes the "least possible behaviour," that is, a behaviour that is not efficient nor legitimate. Power asymmetries and even the recognition that one has a weaker position do not deter cooperation as long as the so-called "cooperation hexagon" (reciprocity, trust, we-identity, enforcement, communication, reputation and fairness) defines the interactions between actors. In other words, this cooperation hexagon is recognized as a guarantee that power asymmetry will not make a significant difference. This guarantee is a precondition for the ripeness of the T2S. 
Lesson 4. Non-linearity and historicity of transformation processes involving series of acceleration, regress, reboot and collapse of the process.

Another important lesson from the theoretical model of T2S is the non-linearity of transformation. T2S is not monolithic nor automatic. T2S depicts the possibility of acceleration (or leapfrogging) regress, reboot and collapse of the process. Moreover, the direct and indirect influences of both positive and negative externalities from other transformation processes imply non-linear trajectories. While the T2S is a process from one departing point to the envisaged outcome, it is not always continuous and automatic. As Figure 1 illustrates, interruptions of the flow are outcomes of changes in the preferences and behaviour of related actors during several bargaining games. In other cases, the resolution of one issue depends on the proper sequencing and alignment to other related issues (e.g., electrification as climate protection measure sequenced with reforms in the energy demand sector). As Frank Geels and Johan Schot [181] note, transitions come about when processes link up and reinforce each other, which may lead to interruptions, as one specific process may not yet be aligned to sustainability. Sequencing of T2S policies takes time and the needed laying the groundwork for more stringent policies to advance T2S can be delayed $[182,183]$. However, as the introduced theoretical model suggests, successful sequencing and adequate alignment can accelerate the transformation process or even allow the skipping (or leapfrogging) of the next phase.

Interruptions are also reflected in the theoretical model as "backward flow" that can be either be a regress or a reboot. A regress refers to the state when actors take one or several steps backwards or even one whole phase back to address an issue that was overlooked or that new sequencing measure are needed. For example, a parliamentary committee that is already evaluating the effects of green energy policies may opt to suspend this evaluation when it recognizes the need to invite new experts to advise them on food security and on other issues. This decision may initially look like a backlash but later on, the gathered knowledge can facilitate or even accelerate the public acceptance of the envisaged policy. A regress is not a transformation failure but it rather depicts the trial-anderror characteristic of the learning process. As new knowledge arises or a new understanding between actors are attained, the T2S can come back to an earlier restore point.

A reboot pertains to the restarting of the transformation process as the actors shift from one entry point to another. This shift is most likely to lead to alternative pathways. One possible rebooting scenario is the fundamental change on what sustainability means. For example, the current conceptualization of sustainable development can be replaced by another concept of sustainability, which can be for the sake of this discussion labelled here as "post-sustainability." When this new understanding entails new set of change/niche players or status quo agents or shift existing power structures, then a reboot is most likely to occur. In addition, exogenous events or externalities can disrupt the T2S for example when new technological innovation is able to shift public opinion or a new legal / political framework enforces fundamental change of course. For example, hypothetically speaking, the German Energiewende can be rebooted if Germany is forced to follow the proposed plan of European Commission plan to classify nuclear energy and gas as sustainable energies [184]. Because the initially chosen entry point to Germany's Energiewende is one that specifically excludes nuclear energy from the start $[101,185,186]$, the EU energy transition might mean a reboot of the German energy transition.

Moreover, besides the backward flow, a collapse or a rupture of the transformation process is possible, which needs to be distinguished from a regress and a reboot. In this scenario, $\mathrm{T} 2 \mathrm{~S}$ ends not because the transformation process is complete, but because the system that hosts the process collapses for reasons related or not related to the process itself. For example, when change actors have become convinced that the current political system does not allow any deep transformational change in the energy system actors 
might finally end their cooperation. In other cases, a collapse can also occur when the contingencies failed to absorb the shocks of transformation lead to cancellation of the transformation process with no decision to choose another entry point nor to determine a new timeline for future negotiations. This can for example happen after efforts to liberalize the energy market has led to higher energy and food prices followed by a series of violent demonstrations. When these demonstrations are able to connect their grievances to a larger conflict context, they can mobilize other groups that are protesting against other grievances such as income inequality. As shown by examples during the Arab spring, a minor issue linked with a larger context of grievances can lead to a popular uprising can topple the government or even the political system $[187,188]$. Under this condition, the transformation process has collapsed because there will be most likely a different set of actors, institutions, structures and even a possibly new set of political norms. In regresses and reboots, changes to these actors, institutions, structures and norms are minimal.

Related to the non-linearity of the T2S is its historicity. While T2S lacks historical precedents in various issues, T2S is still both a non-linear and historical process. Each T2S is historical, because the Zeitgeist or contemporary context is not the only factor that defines the entry points to T2S, the set of actors (and power relations) and the milestones, but also the dynamics of the various previous and parallel events. Entry points to T2S are historical and contextual, because they are defined by experiences (Erlebnisse) from past events and by the current local context (economy, governance, society, etc.). Germany's ability to initiate its ambitious Energiewende is defined by the set of material and immaterial resources the country has at its disposal and which no other country has. The antinuclear and environmental activism that started decades before the Fukushima nuclear incident reflect the narratives, the political culture and values of the German society that have fostered the ripeness of the transformation of its energy system towards sustainability. The German "Sonderweg" (special pathway) is constituted by a framework that defines what is acceptable and at what cost is such an transformation still acceptable $[102,186]$. The country's Energiewende profited by a series of effectively sequenced policies for example in the energy market, public transportation and even in public-private partnerships. The relevant policies have profited from the political emancipation in the 1960s, the expansion of public welfare following the oil crisis in the 1970s and the politicization of environmental protection leading to the mainstreaming of environmental protection $[102,189,190]$. Therefore, T2S is itself a historical event, which makes it difficult to compare and even replicate the T2S experience of Germany for example in Indonesia [191]. This assumption on non-linearity and historicity supports the claim of this paper that T2S does not need to follow Euro- or West-centric perspectives on T2S [3,21].

\section{Conclusions}

Transformation to sustainability is uncomfortable, if not disruptive, because the future is unknown. Yet the future is arriving fast, and it comes with new uncertainties. At the same time, there are many possible routes to this sustainable future and each route has its own set of merits as well as challenges. Each route needs policies and actions that on one hand are effective in addressing the root problems that caused the need for the transformation and on the other hand maintain identity markers through which each one can still identify him or herself to the new normal. What the future entails is not exclusively a matter of power, but more a question of "negotiated" choice. Does everyone have a place in it? Is this sustainable future compatible with one's values, aspirations, and identity? Will this future be a moment of opportunity driven by the spirit of enthusiasm or a moment of resignation and Zukunftsangst (trepidation over what the future brings)? 
The theoretical model is driven by curiosity and the intention to structure complexity to alleviate anxiety towards the outcome of the T2S. Addressing this anxiety is not selfevident and requires process-related provisions. It involves the development of "a roadmap from the present to the desired future" [192] (p. 36). The model can help identify leverage points of T2S by knowing more about human perception, cognition, and motivations for cooperation. It uses the negotiation perspective to prove that this Great Green Transformation can be managed to minimize costs and disruption, hence, ensuring effectiveness and legitimacy. Transformation to sustainability does require, however, additional ambitious and stringent instruments and measures. It propels unprecedented cooperation between stakeholders - both change/niche players and recalcitrant/status quo agents.

This paper concludes by suggesting the next possible steps for future research from this theoretical model. For example, can this model be helpful to understand and explain the current political transitions in countries in the Global South, especially those that are at the same time transitioning from an authoritarian regime? Is T2S only open for democratic countries, as the introduced theoretical model does not explicitly argue for this? Which normative assumptions made by the theoretical model replicate existing Eurocentric views on sustainability? Another possible research outlook on this theoretical model is how various scales reinforce each other. Will the economic transition of India (scale 1) be a game changer in global development (scale 2)? How can the theoretical model explain for example the difficulties in sequencing policies on urban planning with sustainable food production? Another proposition for future research is the linking of social scientific studies on T2S with integrated assessment modelling (IAM) that provides benchmarks for various sustainable pathways. This question also refers to how IAMs can benefit from negotiation insights to develop scenarios of sustainable futures. 
Funding: This research is an outcome of the project SHAPE, which is part of AXIS, an ERA-NET initiated by JPI Climate, and funded by FORMAS (SE), FFG/BMBWF (AT), DLR/BMBF (DE, Grant No. 01LS1907A-B-C), NWO (NL) and RCN (NO) with co-funding by the European Union (Grant No. 776608).

Informed Consent Statement: Not applicable. Data Availability Statement: Not applicable.

Acknowledgments: The author wishes to acknowledge the efforts of Ines Dombrowsky and Gabriela Iacobuta, both colleagues from the German Development Institute, who provided valuable comments to the earlier drafts of this paper. Special thanks is also given to William W. Baber of the Graduate School of Management at the Kyoto University who during the Japan International Society on Negotiation (JISN) Workshop in 2020 and Kent Eaton of the University of California, Santa Cruz, provided feedbacks to the first draft and idea of analysing sustainable development through the academic lens typically used in negotiation studies.

Conflicts of Interest: The authors declare no conflict of interest. 


\section{Appendix A}

Table 1. The German Energiewende - a critical appraisal of the energy transition goals

\begin{tabular}{|c|c|c|c|c|c|}
\hline Goals & Status in 2010 & Status in 2020 & Main drivers of change & Barriers and caveats & Outlook beyond 2020 \\
\hline $\begin{array}{l}\text { Exit from nuclear } \\
\text { energy by } 2022\end{array}$ & $\begin{array}{l}22 \% \text { share of nu- } \\
\text { clear in power mix }\end{array}$ & $\begin{array}{l}11 \% \text { share of nuclear } \\
\text { in power mix, } 76 \text { TWh } \\
\text { reduction from } 2010\end{array}$ & $\begin{array}{c}\text { Electricity shortfall prevented } \\
\text { by RE (despite shutdown of } 8 \\
\text { nuclear power plants in 2011); } \\
\text { strong public resistance } \\
\text { against nuclear power and } \\
\text { nuclear energy waste) } \\
{[99,101,197]}\end{array}$ & $\begin{array}{c}\text { Resistance from neighbors such } \\
\text { as France; EU's definition of nu- } \\
\text { clear energy as green; high com- } \\
\text { pensation for nuclear providers } \\
{[128,184,198]}\end{array}$ & $\begin{array}{l}\text { Optimistic outlook beyond } 2020 \text { as } \\
\text { goal is expected to be achieved } \\
\text { with the last two remaining nu- } \\
\text { clear power plants to be closed be- } \\
\text { tween Dec. } 2021 \text { and Dec. } 2022 \text { or } \\
64 \text { TWh taken off the grid; the Ger- } \\
\text { man federal government agreed to } \\
\text { pay EUR } 2.43 \text { billion as compensa- } \\
\text { tion for loss of revenue and invest- } \\
\text { ment to nuclear power plant own- } \\
\text { ers and operators [128] }\end{array}$ \\
\hline $\begin{array}{l}\text { Guarantee of energy } \\
\text { supply security (in } \\
\text { terms of power out- } \\
\text { age) }\end{array}$ & $\begin{array}{l}14.9 \text { minutes - av- } \\
\text { erage duration of } \\
\text { interruption to } \\
\text { supply per con- } \\
\text { sumer }\end{array}$ & $\begin{array}{l}12.2 \text { minutes - aver- } \\
\text { age duration of in- } \\
\text { terruption to supply } \\
\text { per consumer }\end{array}$ & $\begin{array}{l}\text { Increase of share of RE; diver- } \\
\text { sification of oil supply } \\
\text { sources; a well-connected } \\
\text { supply infrastructure; liberal } \\
\text { market; and high oil emer- } \\
\text { gency reserves [99,195] }\end{array}$ & $\begin{array}{l}\text { Nuclear phase-out; heavy reli- } \\
\text { ance on gas imports (93\% of sup- } \\
\text { ply); geopolitical tensions involv- } \\
\text { ing the United States and Russia } \\
{[99,197]}\end{array}$ & $\begin{array}{l}\text { Optimistic outlook as the Federal } \\
\text { Network Agency (Bundesnet- } \\
\text { zagentur) sees no negative impact } \\
\text { on the quality of power supply } \\
\text { due to the nuclear energy phase- }\end{array}$ \\
\hline
\end{tabular}


out; energy self-sufficiency remains stable with around $40 \%$ of TPES [199]

\begin{abstract}
Expansion of use of renewables $(35 \%$ share of renewables in electricity generation by $2020 ; 50 \%$ by $2030 ; 65 \%$ by 2040 ; $80 \%$ by 2050$)$
\end{abstract}

\section{$17 \%$ share of RE \\ (incl. 6\% wind \& \\ $2 \%$ solar)}

$45 \%$ (incl. biowaste

from households)

New wind and solar plants

now competitive with con-

wind \& 9\% solar); 150 technologies; electricity gener- charge) (from EUR $23.4 \mathrm{ct} / \mathrm{kWh}$

TWh more than 2010 ation through RE significantly in 2010 to $32.05 \mathrm{ct} / \mathrm{kWh}$ in 2020)

cheaper than electricity from and due to increase of average

nuclear power; ICT innova- cost of electricity to maintain ex-

tion allowing more real-time cess of installed power; re-

information of electricity sistance from neighbor countries source; reforms of the electric- Poland and Czech Republic due

ity market regulation to the integrated European en-

$$
[102,127,195] \quad \text { ergy market [200-202] }
$$

Enhancement of energy efficiency $(20 \%$ reduction in primary energy consumption by 2020 and $50 \%$ by 2050 , base year 2008)

\section{Electricity final 594.19 TWh}

$20 \%$ reduction in pri- $\mathrm{COV}$
mary energy consumption ing and increasing energy low motivation of tenants to inprice $[99,126,127]$ vest in $\mathrm{EE}$; heritage protection regulations in historical buildings; rent price caps leading to tech less investment of landlords

Optimistic outlook beyond 2020 due to increased public acceptance of RE, solid political support from all major political parties, and enhanced competitiveness of RE.

Cost of fossil power plants depends crucially on the cost of $\mathrm{CO} 2$.

More RE needed to replace nuclear in a carbon neutral way $[99,195]$ Pessimistic outlook beyond 2020 as tion in ICT and IoT; CO2 pric- ings; split incentive barrier or electricity consumption is expected

to rise in 2021 and 2022 (after the COVID-19 pandemic) due to increased economic output and slow technological innovation in battery $[101,201]$

Reduction of final $27.5 \%$ share of $\quad 2017: 26 \%$ share COVID-19 pandemic, innova- Tourism; delays in digitalization Pessimistic outlook beyond 2020 as energy consumption transport sector in 2019: 7.2\% increase of tion in smart technologies and projects; concerns on data protec- energy consumption of the of the transport sec- final energy con- final energy con- IoT; political culture and tion; different mobility needs be- transport sector is expected to intor $(10 \%$ reduction sumption sumption of the grassroot movements; policy tween urban and rural areas; car- crease due to slow and expensive by $2020,40 \%$ reduc- 53,149 ktoe total fi- transport sector; 2018: incentives such as Abwrack- bon lock-ins, e-commerce; social technological innovation in freight tion by 2050 , base nal consumption: 56,141 ktoe; $2.2 \%$ inyear: $2005,54923 \quad 3.2 \%$ reduction or ktoe) 1,774 ktoe lower than 2005 crease (1218 ktoe) prämie and tax breaks for electro cars; $\mathrm{CO} 2$ pricing for emissions $[129,130,194]$ justice issues, failure to internal- transport (sea and air) $[99,101]$

ize negative externalities of car usage; public resistance against elimination of diesel privileges and speed limits $[193,204]$ 


\section{References}

1. Lam, D.; Martín-López, B.; Wiek, A.; Bennett, E.; Frantzeskaki, N.; Horcea-Milcu, A.; Lang, D. Scaling the impact of sustainability initiatives: a typology of amplification processes. Urban Transformations 2020, 2.

2. Hopwood, B.; Mellor, M.; O'Brien, G. Sustainable development: Mapping different approaches. Sustainable Development 2005, 13, 38-52 doi:10.1002/sd.244.

3. Hernandez, A. Taming the Green Elephant. Setting In Motion towards Transformation to Sustainability; Springer VS: Wiesbaden, 2021.

4. Curran, J.; Gaber, I.; Petley, J. Culture Wars. The Media and the British Left; Routledge: London, 2019.

5. Anthony, A. Everything you wanted to know about the culture wars - but were afraid to ask. The Guardian 2021.

6. Simmons, K.; Silver, L.; Johnson, C.; Wike, R. In Western Europe, Populist Parties Tap Anti-Establishment Frustration but Have Little Appeal Across Ideological Divide; Pew Research Center: Washington, D.C., 2018.

7. Najam, A. The View from the South: Developing Countries in Global Environmental Politics. In The Global Environment: Institutions, Law, and Policy, Axelrod, R.S., Downie, D.L., Vig, N.J., Eds. CQ Press: Washington, D.C., 2010.

8. Penetrante, A.M. The Entanglement of Climate Change in North-South Relations: Stumbling Blocks and Opportunities for Negotiation. In Climate Change: Global Risks, Challenges and Decisions, Richardson, K., Will, S., Livermann, D., Eds. Cambridge Univeristy Press: Cambridge, UK, 2011; pp. 356-359.

9. Duffy, R. Global environmental governance and North-South dynamics: the case of the CITES. Environment and Planning C-Government and Policy 2013, 31, 222-239, doi:10.1068/c1105.

10. System innovation and the transition to sustainability: Theory, evidence and policy. Elzen, B.; Geels, F.W.; Green, K., Eds.; Edward Elgar: Cheltenham, UK; Northhampton, MA, USA, 2004; 10.4337/9781845423421.

11. Fazey, I.; Moug, P.; Allen, S.; Beckmann, K.; Blackwood, D.; Bonaventura, M.; Burnett, K.; Danson, M.; Falconer, R.; Gagnon, A.S., et al. Transformation in a changing climate: a research agenda. Climate and Development 2018, 10, 197-217, doi:10.1080/17565529.2017.1301864.

12. Dasgupta, C. The Climate Change Negotiations. In Negotiating Climate Change: The Inside Story of the Rio Convention, Mintzer, I., Leonard, J.A., Eds. Cambridge University Press: Cambridge, UK, 1994; pp. 129-148 \%! Dasgupta 1994 - The Climate Change Negotiations.

13. Climate Change Negotiations. A Guide to Resolving Disputes and Facilitating Multilateral Cooperation. Sjöstedt, G.; Penetrante, A.M., Eds.; Routledge: London, 2013.

14. Kjellén, B. The New Diplomacy from the Perspective of a Diplomat: Facilitation of the Post-Kyoto Climate Talks. In Climate Change Negotiations. A Guide to Resolving Disputes and Facilitating Multilateral Cooperation, Sjöstedt, G., Penetrante, A.M., Eds. Routledge: London, 2013; pp. 48-62.

15. Kempel, W. Transboundary Movements of Hazardous Wastes. In International Environmental Negotiation, Sjöstedt, G., Ed. Sage: Newbury Park, 1993; pp. 48-62.

16. International Environmental Negotiations. Sjöstedt, G., Ed.; SAGE Publications: Newbury Park, London \& New Delhi, 1993.

17. Chasek, P. Earth Negotiations: Analyzing Thirty Years of Environmental Diplomacy; UNU Press Tokyo, 2001.

18. Velasquez, G. The right to health and medicines: the case of recent multilateral negotiations on public health, innovation and intellectual property. Dev World Bioeth. 2014, 14, 67-74.

19. Fairman, D.; Chigas, D.; McClintock, E.; Drager, N. Negotiating Public Health in a Globalized World; Springer Netherlands: Dordrecht, 2012.

20. Hernandez, A. Facilitar la toma de decisiones - Escenarios de transformación de las economías bajas en carbon. In Perspectivas de Sustentabilidad en México, Rodriguez, A., Ed. Universidad Autónoma del Estado de Morelos: Cuernavaca, Mexico, 2017.

21. Hernandez, A. SDG-aligned Futures and the Governance of Transformation to Sustainability. Reconsidering Governance Perspectives on the Futures We Aspire to DIE Discussion Paper Series 2021, 10.23661/dp30.2021, doi:10.23661/dp30.2021.

22. Hernandez, A. Knowledge Diplomacy and the Future(s) of Global Cooperation. E-International Relations 2021.

23. Hernandez, A.M. A Principle of Equitable Access to Sustainable Development - Internalizing Externalities in the Global Climate Talks. Review of Business and Economics Studies 2014, 2, 74-87.

24. Hernandez, A.M. Migration and "Unfinished" Modernization in the Philippines, Indonesia and Mexico. In Migración internacional: voces del sur, González Becerril, J.G.M.A., Bernardino Jaciel \& Sandoval Forero, Eduardo Andrés Ed. Universidad Autónoma del Estado de México: Toluca, Mexico, 2017; pp. 265-282.

25. Buzan, B.; Lawson, G. The Global Transformation: History, Modernity and the Making of International Relations; Cambridge University Press \%! Buzan, Lawson 2015 - The Global Transformation: Cambridge, UK, 2015.

26. Fücks, R. The Great (Green) Transformation. Heinrich Böll Stiftung: Berlin, 2011.

27. Bebbington, J.; Unerman, J. Achieving the United Nations Sustainable Development Goals: An enabling role for accounting research. Accounting Auditing \& Accountability Journal 2018, 31, 2-24, doi:10.1108/aaaj-05-2017-2929.

28. Chan, S.; Iacobuta, G.; Hägele, R. Maximising goal coherence in sustainable and climate-resilient development? Polycentricity and coordination in governance. In The Palgrave Handbook of development cooperation for achieving the 2030 
Agenda, Chaturvedi, S., Janus, H., Klingebiel, S., de Mello e Souza, A., Sidiropoulos, E., Wehrmann, D., Eds. Palgrave Macmillan: Cham, 2020; pp. 25-50.

29. UN. Transforming our World: The 2030 Agenda for Sustainable Development; United Nations: New York, 2015.

30. Sun, C.W.; Yuan, X.; Yao, X. Social acceptance towards the air pollution in China: Evidence from public's willingness to pay for smog mitigation. Energy Policy 2016, 92, 313-324, doi:10.1016/j.enpol.2016.02.025.

31. Cao, W.; Wang, H.; Ying, H. The Effect of Environmental Regulation on Employment in Resource-Based Areas of ChinaAn Empirical Research Based on the Mediating Effect Model. International Journal of Environmental Research and Public Health 2017, 14, 1598, doi:10.3390/ijerph14121598.

32. Chen, Y.X.; Zhang, J.; Tadikamalla, P.R.; Gao, X.T. The Relationship among Government, Enterprise, and Public in Environmental Governance from the Perspective of Multi-Player Evolutionary Game. International Journal of Environmental Research and Public Health 2019, 16, doi:10.3390/ijerph16183351.

33. Öhm, M. Towards Geopolitical German Development Cooperation? Recent History, Current Trends and Future Prospects; The French Institute of International Relations (IFRI): Paris, 2021.

34. Gambhir, A.; Butnar, I.; Pei-Hao, L.; Smith, P.; Strachan, N. A Review of Criticisms of Integrated Assessment Models and Proposed Approaches to Address These, through the Lens of BECCS. Energies 2019, 12, 1747.

35. Wei, P.; Iyer, G.; Bosetti, V.; Chaturvedi, V.; Edmonds, J.; Fawcett, A.; Hellegatte, S.; Victor, D.; van Vuuren, D.; Weyant, J. Climate policy models need to get real about people - here's how. Nature 2021, 594, 174-176.

36. Hernandez, A. Setting Sustainable Low Carbon Development in Motion - Integrated and Negotiative Perspectives on Transformation Pathways, Habilitation. University of Duisburg-Essen, 2018.

37. Keppo, I.; Butnar, I.; Bauer, N.; Caspani, M.; Edelenbos, O.; Emmerling, J.; Fragkos, P.; Guivarch, C.; Harmsen, M.; Lefevre, J., et al. Exploring the possibility space: Taking stock of the diverse capabilities and gaps in integrated assessment models. Environmental Research Letters 2020, 16, 053006.

38. de Ferrer, M. Why is environmentalism more popular in LGBTQ+ communities?. Euronews 2020.

39. Cohen, I. Across America, Activists Work at the Confluence of LGBTQ Rights and Climate Justice. Inside Climate News 2020.

40. 40.Willy, K. Feature: Why LGBTQI communities will be disproportionately affected by the climate crisis. Environmental Journal 2021.

41. Heggelund, G. China's climate change policy: deomestic and international developments. Asian Perspective 2007, 31, 155191

42. He, J.-K. Global low-carbon transition and China's response strategies. Advances in Climate Change Research 2016, 7, 204212, doi:10.1016/j.accre.2016.06.007.

43. 43.Wenxian, Z.; Alon, I.; Lattemann, C. China's Belt and Road Initiative. Changing the Rules of Globalization; Palgrave Macmillan: London, 2020.

44. Zartman, I.W. Ripe for Resolution; Oxford University Press: Oxford, 1989.

45. Zartman, I.W. Prenegotiation: Phases and Functions. International Journal 1989, 44, 237-253.

46. Rojot, J. The Phases of Negotiation. In Negotiation: From Theory to Practice, Rojot, J., Ed. Palgrave Macmillan: London, 1991; pp. 174-196.

47. Complexity in International Negotiations. Druckman, D., Ed.; Sage Beverly Hills, 1977.

48. Baber, W. Identifying Macro Phases Across the Negotiation Lifecycle. Group Decision and Negotiation 2018, $27,885-903$.

49. Druckman, D. Conflict Escalation and Negotiation: A Turning Point Analysis. In Escalation and Negotiation in International Conflicts, Zartman, I.W., Ed. Cambridge University Press: Cambridge, 2005; pp. 185-212.

50. Brett, J.; Weingart, L.; Olekalns, M. Baubles, bangles, and beads: modeling the evolution of negotiating groups over time; JAI Press: Stamford, 2003; Vol. Vol. 6.

51. Lui, P.; Liu, J. Contribution diversity and incremental learning promote cooperation in public goods games. Physica A: Statistical Mechanics and its Applications 2017, 486, 827-838.

52. Walsh, J.P. Managerial and organizational cognition: Notes from a trip down memory lane. Organization Science 1995, 6, 280-321

53. Smith, W.K.; Tushman, M.L. Managing strategic contradictions: A top management model for managing innovation streams. Organization Science 2005, 16, 522-536.

54. Hopmann, P.T. The Negotiation Process and the Resolution of International Conflicts; University of South Carolina Press Columbia, SC, 1996.

55. Balzacq, T. The Three Faces of Securitization: Political Agency, Audience and Context. European Journal of International Relations 2005, 11, 171-201.

56. Waever, O. Politics, Security, Theory. Security Dialogue 2011, 42, 465-480.

57. Weaver, A. The Science of Climate Change. In Hard Choices: Climate Change in Canada, Coward, H., Waever, A., Eds. Wilfrid Laurier University Press: Waterloo, Ontario, 2004; pp. 13-43

58. Hernandez, A.; Misalucha-Willoughby, C. Securitization of Climate and Environmental Protection in China's New Normal. Decision-Making in Public Policy \& the Social Good eJournal 2020, http://dx.doi.org/10.2139/ssrn.3686466, doi:http://dx.doi.org/10.2139/ssrn.3686466. 
59. Zartman, I.W. The Negotiation Process: Theories and Applications; SAGE Publications Beverly Hills, CA, 1978.

60. Zartman, I.W. Common Elements in the Analysis of the Negotiation Process. Negotiation Journal 1988, 4, 31-43

61. Young, H.P. Negotiation Analysis; University of Michigan Press Ann Arbor, MI, 1991.

62. OECD. Costs of Inaction on Key Environmental Challenges; Organisation for Economic Cooperation and Development (OECD): Paris, 2008.

63. International Regimes. Krasner, S., Ed.; Cornell University Press Ithaca, NY, 1983.

64. Bauer, O. Die Nationalitätenfrage und die Sozaldemokratie; Verlag der Wiener Volksbuchhandlung Ignaz Brand Wien, 1907.

65. Renner, K. Die Nation als Rechtsidee und die Internationale; Verlag des Vereines - in Komission bei der Wiener Volksbuchhandlung Ignaz Brand \& Co: Wien, 1914.

66. Negotiation as a Social Process: New Trends in Theory and Research. Kramer, R.; Messick, D., Eds.; Sage: Thousand Oaks, CA, 1995.

67. Cross, J. Negotiation as Adaptive Learning. International Negotiation 1996, 1, 153-178

68. Brams, S. Newcomb's Problem and Prisoners' Dilemma. The Journal of Conflict Resolution 1975, 19, 596-612.

69. Snidal, D. Coordination versus Prisoner's Dilemma: Implications for International Cooperation and Regimes. In International Institutions, Goldstein, J., Steinberg, R.H., Eds. Sage: Los Angeles, London, New Delhi, Singapore, Washington DC, 2010; pp. 1-32.

70. Zartman, I.W.; Berman, M. The Practical Negotiator; Yale University Press New Haven, Conn., 1982.

71. Touval, S.; Zartman, I.W. International Mediation in Theory and Practice; Westview Press/Foreign Policy Institute, School of Advanced International Studies, Johns Hopkins University Boulder, CO, 1985.

72. Thorstensen, V.; Correa, R.; Brito, D.; Hernandez, A.; Arima, M.K.J.; Reboucas Mota, C.; Megale, T.; Mitsue Zuchieri, A.; Thomazella, F.J. Voluntary Sustainability Standards (VSS) in Polluting Sectors in Brazil; Deutsches Institut für Entwicklungspolitik/ German Development Institute: Bonn, Germany, 2022 (submitted).

73. Power and Negotiation. Zartman, I.W.; Rubin, J., Eds.; University of Michigan Press: Ann Arbor, MI, 2000.

74. Kingdon, J. Agendas, Alternatives and Public Policies; Little, Brown and Company: Boston, 1984.

75. Chhotray, V.; Stoker, G. Governance Theory and Practice. A Cross-Disciplinary Approach; Palgrave Macmillian: New York City, 2009.

76. Kooiman, J. Modern Governance: New Government-Society Interactions; SAGE Publications Thousand Oaks, CA, 1993.

77. Mayntz, R. New Challenges to Governance Theory. In Governance as Social and Political Communication, Bang, H.P., Ed. Manchester University Press: Manchester, 2003; pp. 27-40.

78. Galaz, V.; Biermann, F.; Folke, C.; Nilsson, M.; Olsson, P. Global environmental governance and planetary boundaries: An introduction. Ecological Economics 2012, 81, 1-3, doi:10.1016/j.ecolecon.2012.02.023.

79. Rockstrom, J.; Steffen, W.; Noone, K.; Persson, A.; Chapin, F.S.; Lambin, E.; Lenton, T.M.; Scheffer, M.; Folke, C.; Schellnhuber, H.J., et al. Planetary Boundaries: Exploring the Safe Operating Space for Humanity. Ecology and Society $2009,14$.

80. Cadman, T. Climate change and global policy regimes: Towards institutional legitimacy; Palgrave Macmillan: Basingstoke, 2013.

81. Carlnaes, W. The Agent-Structure Problem in Foreign Policy Analysis. International Studies Quarterly 1992, 36, 245-270

82. Chan, S.; Boran, I.; Van Asselt, H.; Iacobuta, G.; Niles, N.; Rietig, M.; Scobie, M.; Bansard, J.; Delgado, D.; Delina, L., et al. Promises and Risks of Non-State Actions in Climate and Sustainability Governance. WIREs Climate Change 2019, 10 , e572.

83. Zengerling, C. Greening International Jurisprudence. Environmental NGOs before International Courts, Tribunals, and Compliance Committees; Brill Nijhoff: Leiden, 2013; Vol. 17.

84. Theories of the Policy Process. Sabatier, P., Ed.; Westview Press: Boulder, CO, 2009.

85. Readfearn, G. Australian government must protect young people from climate crisis harm, court declares. The Guardian 8 July 2021, 2021.

86. Mintrom, M.; Norman, P. Policy Entrepreneurship and Policy Change. Policy Studies Journal 2009, 37, $649-667$.

87. Arias-Maldonado, M. An imaginary solution? The green defence of deliberative democracy. Environmental Values 2007, $16,233-252$

88. Bovermann, P. Pause für die Weltretter. Süddeutsche Zeitung 09.04.2020, 2020.

89. Schröder, T. Die positiven Erfahrungen mitnehmen. Süddeutsche Zeitung 22.03.2020, 2020.

90. Ayling, J.; Gunningham, N. Non-state governance and climate policy: the fossil fuel divestment movement. Climate Policy 2017, 17, 131-149, doi:10.1080/14693062.2015.1094729.

91. Biermann, F.; Pattberg, P. Global Environmental Governance: Taking Stock, Moving Forward. Annu Rev Env Resour 2008, 33, 277-294, doi:10.1146/annurev.environ.33.050707.085733.

92. Nonprofits and Advocacy: Engaging Community and Government in an Era of Retrenchment. Pekkanen, R.; Smith, S.R.; Tsujinaka, Y., Eds.; Johns Hopkins University Press: 2014; p 1 online resource \%! Pekkanen, Smith et al. (Ed.) 2014 - Nonprofits and Advocacy.

93. Winham, G.; DeBoer-Ashworth, E. Asymmetry in Negotiating the Canada-US Free Trade Agreement, 1985-1987. In Power and Negotiation, Zartman, I.W., Rubin, J., Eds. University of Michigan Press: Ann Arbor, MI, 2000; pp. 35-52. 
94. Messner, D.; Guarín, A.; Haun, D. The Behavioural Dimensions of International Cooperation. Käte Hamburger Kolleg / Centre for Global Cooperation Research: Duisburg, 2013.

95. Messner, D.; Guarín, A.; Haun, D. Putting Behavior into International Cooperation. The Chinese Journal of Global Governance 2016, 2, 129-141.

96. Bruckner, T.; Petschel-Held, G.; Toth, F.L.; Füssel, H.M.; Helm, C.; Leimbach, M.; Schnellnhuber, H.J. Climate change decision-support and the tolerable windows approach. 1999, 4, 217-234

97. Petschel-Held, G.; Schellnhuber, H.-J.; Bruckner, T.; Tóth, F.L.; Hasselmann, K. The Tolerable Window Approach: Theoretical and Methodological Foundations. Climatic Change 1999, 41, 303-331 doi:10.1023/A:1005487123751.

98. Hentschel, V. Ludwig Erhard, die "soziale Marktwirtschaft" und das Wirtschaftswunder. Historisches Lehrstück oder Mythos?; Bouvier Verlag: Bonn, 1998.

99. IEA. Germany 2020. Energy Policy Review; International Energy Agency: Paris, 2020.

100. WBGU. World in Transition. A Social Contract for Sustainability. German Advisory Council on Global Change: Berlin, 2011.

101. Agora Energiewende. 10 Years after Fukushima: Consequences of the Nuclear Phase-Out for the Energy Transition; Agora Energiewende: Berlin, 2021.

102. Hennicke, P.; Welfens, P.J.J. Energiewende nach Fukushima: Deutscher Sonderweg oder weltweites Vorbild?; Oekom Verlag: München, 2012; pp. 1 online resource \%! Hennicke, Welfens 2012 - Energiewende nach Fukushima.

103. Dietsche, H.-J. Energiewende und Energie-Föderalismus - Zu den Möglichkeiten für eine Koordination des Ausbaus der erneuerbaren Energien im Bundesstaat. In Jahrbuch des Föderalismus 2013. Föderalismus, Subsidiarität und Regionen in Europa, (EZFF), E.Z.f.F.-F.T., Ed. Nomos: Baden Baden, 2013; pp. 47-54.

104. Pittel, K.; Henning, H.-M. Was uns die Energiewende wirklich kosten wird. Frankfurter Allgemeine Zeitung July 12, 2019 , 2019.

105. Focus. Verwaltungsgericht droht Klagewelle wegen Energiewende. Online Focus 2013.

106. Eckerieder, S. Konzernklage gegen Energiewende explodieren. Tiroler Tageszeitung October 15, $2019,2019$.

107. BMWi. Abschlussbericht. Kommission "Wachstum, Strukturwandel und Beschäftigung"; Bundesministerium für Wirtschaft und Energie: Frankfurt am Main, 2019.

108. Kopatz, M.; Spitzer, M.; Christanell, A. Energiearmut: Stand der Forschung, nationale Programme und regionale Modellprojekte in Deutschland, Österreich und Großbritannien; Wuppertal Institut: Wuppertal, 2010.

109. Schäfer, A. Krisentheorien der Demokratie: Unregierbarkeit, Spätkapitalismus und Postdemokratie. MPIfGDiscussion Paper 2010.

110. Crouch, C. Postdemokratie; Suhrkamp Verlag: Frankfurt am Main, 2008.

111. Penetrante, A.M. Postdemokratie. In Politik begreifen, Falter, M., Löffler, M., Schmidinger, T., Schwediauer, V., Stachowitsch, S., Eds. Braumüller Wien, 2009.

112. Ingram, M.; Ingram, H.; Lejano, R. Environmental Action in the Anthropocene: The Power of Narrative Networks. Journal of Environmental Policy \& Planning 2019, 21, 492-503, doi:10.1080/1523908x.2015.1113513.

113. Warner, B.P. Explaining political polarization in environmental governance using narrative analysis. Ecology and Society 2019, 24, doi:10.5751/es-10999-240304.

114. Fricko, O.; Havlik, P.; Rogelj, J.; Klimont, Z.; Gusti, M.; Johnson, N.; Kolp, P.; Strubegger, M.; Valin, H.; Amann, M., et al. The marker quantification of the Shared Socioeconomic Pathway 2: A middle-of-the-road scenario for the 21st century. Global Environmental Change 2017, 42, 251-267.

115. BTI. Hungary - BTI Transformation Index; Bertelsmann Stiftung: Gütersloh, 2022.

116. BTI. Poland - BTI Transformation Index; Bertelsmann Stiftung: Gütersloh, 2022.

117. De Giorgi, E. The never-ending transformation of the Italian party system. In Party System Change, the European Crisis and the State of Democracy, Lisi, M., Ed. Routledge: London, 2018; pp. 155-170.

118. Hernandez, A.M.; Pacheco Rojas, D.A.; Barrón Villaverde, D. Carbon Lock-In and Contradictions-Applied Guide to Academic Teaching of Mexico's Energy Transition Applied Sciences 2021, 11, 8289, doi:https://doi.org/10.3390/app11188289.

119. Unruh, G. Escaping carbon lock-in. Energy Policy 2002, 30, 317-325.

120. Unruh, G. Understanding carbon lock-in. Energy Policy 2000, 28, 817-830.

121. Arthur, B. Competing Technologies, Increasing Returns and Lock-In by Historical Events. Economic Journal 1989, $99,116-$ 131.

122. Liebowitz, S.; Margolis, S. Path Dependence, Lock-In and History. Journal of Law, Economics \& Organization 1994, 11, 205-226.

123. Moore, M.-L.; Riddell, D.; Vicisano, D. Scaling Out, Scaling Up, Scaling Deep: Strategies of Non-profits in Advancing Systemic Social Innovation. Journal of Corporate Citizenship 2015, 58, 67-84, doi:https://doi.org/10.9774/gleaf.4700.2015.ju.00009.

124. Grass, H. Wann ist die Energiewende aus Ihrer Sicht abgeschlossen?; Stiftung Energie und Klimaschutz: Karlsruhe, 2014.

125. Cvitanovic, C.; Hobday, A.J.; van Kerkhoff, L.; Wilson, S.K.; Dobbs, K.; Marshall, N.A. Improving knowledge exchange among scientists and decisionmakers to facilitate the adaptive governance of marine resources: A review of knowledge and research needs. Ocean \& Coastal Management 2015, 112, 25-35, doi:10.1016/j.ocecoaman.2015.05.002. 
126. BMWi. Gesamtausgabe der Energiedaten - Datensammlung des BMWi; Bundesministrerium für Wirtschaft und Energie: Berlin, 2020.

127. BMWi. Die Energie der Zukunft. 8. Monitoring-Bericht zur Energiewende. Berichtsjahre 2018 und 2019; Bundesministerium für Wirtschaft und Energie: Berlin, 2021.

128. Reuters. Germany to pay nuclear operators 2.6 billion euros for plant closures. Reuters 2021.

129. Frey, K.; Burger, A.; Dziekan, K.; Bunge, C.; Lünenbürger, B. Verkehrswende für Alle; Umweltbundesamt: Dessau, 2020.

130. Rudolph, F.; Koska, T.; Schneider, C. Verkehrswende für Deutschland. Der Weg zu CO2-freier Mobilität bis 2035; Wuppertal Institut: 2017.

131. AgrarBündnis. Der kritische Agrarbericht; AgrarBündnis: Konstanz, 2022.

132. Zaremba, N.; Schlandt, J. Was kostet der Kohleaustrieg? Der Tagesspiegel 2019.

133. Maas, H. How to make the energiewende an export hit; Federal Foreign Office: Berlin, 2019.

134. Steinbacher, K. Exporting the Energiewende; Springer VS: Wiesbaden, 2019.

135. BMZ. BMZ 2030 reform strategy. New thinking - new direction; Federal Ministry for Economic Cooperation and Development (BMZ): Berlin, 2020.

136. BMZ. BMZ-Kernthemenstrategie: Verantwortung für unseren Planeten - Klima und Energie; Bundesministerium für wirtschaftliche Zusammenarbeit und Entwicklung (BMZ): Bonn, 2021.

137. Narita, J. Korean-German Energy Partnership - 1st Meeting of the Energy Transition Working Group. Adelphi 2020.

138. Vogel, J.; Schwachula, A.; Reiber, T. Bridging the North-South Knowledge divide through transnational knowledge cooperation: Towards a research agenda. In Proceedings of International Conference on Sustainable Development 2019 - Good Practice: Models, Partnerships, and Capacity Building for the SDGs New York.

139. Hernandez, A.M. Knowledge Diplomacy in Climate Politics: Global Policy-Making through Regional Lens. In The Routledge Handbook on Transregional Studies, Middell, M., Ed. Routledge: London, 2018; pp. 582-588.

140. Folke, C.; Hahn, T.; Olsson, P.; Norberg, J. Adaptive governance of social-ecological systems. Annu Rev Env Resour 2005, 30, 441-473, doi:10.1146/annurev.energy.30.050504.144511.

141. Cote, M.; Nightingale, A.J. Resilience thinking meets social theory: Situating social change in socio-ecological systems (SES) research. Progress in Human Geography 2012, 36, 475-489, doi:10.1177/0309132511425708.

142. Brand, F.; Jax, K. Focusing the Measning(s) of Resilience: Resilience as a Descriptive Concept and a Boundary Object. Ecology and Society 2007, 12, 23.

143. Brown, K. Global environmental change I: A social turn for resilience? Progress in Human Geography 2014, 38, 107-117, doi:10.1177/0309132513498837.

144. Folke, C.; Carpenter, S.R.; Walker, B.; Scheffer, M.; Chapin, T.; Rockström, J. Resilience Thinking: Integrating Resilience, Adaptability and Transformability. Ecology and Society 2010, 15, 20.

145. Thorén, H. Resilience as a Unifying Concept. International Studies in the Philosophy of Science 2014, $28,303-324$.

146. Rizzi, F.; van Eck, N.J.; Frey, M. The production of scientific knowledge on renewable energies: Worldwide trends, dynamics and challenges and implications for management. Renewable Energy 2014, 62, 657-671.

147. Elkington, J.; Burke, T. The Green Capitalists; Gollancz: London, 1987.

148. Elkington, J. Towards the Sustainable Corporation: Win-Win-Win Business Strategies for Sustainable Development. California Management Review 1994, 36, 90-100

149. Lomborg, B. The Sceptical Environmentalists: Measuring the Reat State of the World; Cambridge University Press: Cambridge, 2001.

150. Beck, U. The Risk Society; Sage: London, 1992.

151. Jacobs, M. Environmental Modernisation: the New Labour Agenda; Fabian Society: London, 1999.

152. Lübker, H.M.; Abson, D.; Riechers, M. Discourses for deep transformation: perceptions of economic growth in two rural communities in Lower Saxony, Germany. Sustainability Science 2021, 16, 1827-1840.

153. Power Shifts and Global Governance. Challenges from South and North. Kumar, A.; Messner, D., Eds.; Anthem Press: London \& New York, 2010.

154. George, S. The Lugano Report; Pluto: London, 1999.

155. Rees, W. Achieving sustainability: reform or transformation? Journal of Planning Literature 1995, 9, 343-361.

156. Schot, J.; Steinmueller, W.E. Three frames for innovation policy: R\&D, systems of innovation and transformative change. Research Policy 2018, 47, 1554-1567, doi:10.1016/j.respol.2018.08.011.

157. Reyes Hernandez, D.H. Propuesta de un modelo de innovación para rediseñar la gestión en la investigación y desarrollo dentro de la cadena de valor de los hidrocarburos en México. Technológico de Monterrey, Monterrey, 2020.

158. Leggewie, C.; Messner, D. The low-carbon transformation-A social science perspective. Journal of Renewable and Sustainable Energy 2012, 4, 041404.

159. Messner, D. Transformation zur Nachhaltigkeit: Perspektiven für Nordrhein-Westfallen in einem globalen Strukturwandel. Exzellenz: das Clustermagazin Nordrhein-Westfallen 2014, 14-15.

160. Velasco-Herrejon, P.; Bauwens, T. Energy justice from the bottom up: A capability approach to community acceptance of wind energy in Mexico. Energy Research \& Social Science 2020, 70, 101711. 
161. Halim, S.A.A.-A., Philip; Dasgupta, Purnamita; Hayward, Bronwyn; Kanninen Markku; Liverman, Diana; Okereke, Chukwumerije; Pinho, Patricia Fernanda; Riahi, Keywan; Rodriguez, Avelino G. Suarez. Sustainable Development, Poverty Eradication and Reducing Inequalities; IPCC: 2018; pp 445 - 538.

162. Sarkar, S. Eco-Socialism or Eco-Capitalism?; Zed: London, 1999.

163. Pepper, D. Eco-Socialism: from Deep Ecology to Social Justice; Routledge: London, 1993.

164. McCarthy, N. The Growing Cost Of The Royal Family To U.K. Taxpayers [Infographic]. Forbes 2021.

165. Child, A. There's every reason to argue that it's time to abolish the Monarchy. Britain can do so much better. London School of Economics and Politics: London, 2012; Vol. 2022.

166. Blond, P. In defence of Kings and Queens: why the monarch matters. BBC News 2010.

167. Meadows, D. Leverage points: places to intervene in a system; The Sustainability Institute: Hartland, 1999.

168. Fischer, J.; Riechers, M. A leverage points perspective on sustainability. People and Nature 2019, 1, 115-120.

169. Hamilton, W. The evolution of altruistic behaviour. American Naturalist 1963, 97, 354-356.

170. Grafen, A. Optimisation of inclusive fitness. Journal of Theoretical Biology 2006, 238, 541-563.

171. Axelrod, R. The Evolution of Cooperation; Basic Books: New York, 1984.

172. Trivers, R. The evolution of reciprocal altriusm. Quarterly Review of Biology 1971, 46, 35-57.

173. Axelrod, R.; Hamilton, W. The evolution of cooperation. Science 1981, 211, 1390-1396.

174. Luce, R.D.; Raiffa, H. Games and Decisions; Wiley New York, 1957.

175. Oye, K.A. Explaining Cooperation under Anarchy: Hypotheses and Strategies. World Politics 2011, 38, 1-24

176. Conflict, Cooperation, and Justice. Bunker, B.; Rubin, J., Eds.; Jossey-Bass Publishers: San Francisco, 1995.

177. Tversky, A.; Kahnemann, D. Rational Choice and the Framing of Decisions. The Journal of Business 1986, 59, S251-S278.

178. Goldsmith, J.; Posner, E. International Agreements: A Rational Choice Approach. In International Institutions, Goldstein, J., Steinberg, R.H., Eds. Sage: Los Angeles, London, New Delhi, Singapore, Washington DC, 2010; pp. 365-390

179. Paul, L.A. Transformative Experience; Oxford University Press: Oxford, 2014.

180. 180. Bykvist, K.; Strefánsson, H.O. Epistemic Transformation and Rational Choice. Economics and Philosophy 2017, 33, 125-138.

181. Geels, F.; Schot, J. The dynamics of socio-technical transitions: A socio-technical perspective. In Transitions to sustainable development - New directions in the study of long term transformative change, Grin, J., Rotmans, J., Schot, J., Eds. Routledge: London, 2009; pp. 11-104

182. Meckling, J.; Sterner, T.; Wagner, G. Policy sequencing toward decarbonization. Nature Energy 2017, 10.1038/s41560-0170025-8, doi:10.1038/s41560-017-0025-8.

183. Pahle, M.; Burtraw, D.; Flachsland, C.; Kelsey, N.; Biber, E.; Meckling, J.; Edenhofer, O.; Zysman, J. Sequencing to ratchet up climate policy stringency. Nature Climate Change 2018, 8, 861-867.

184. Alderman, L.; Pronczuk, M. Europe Plans to Say Nuclear Power and Natural Gas Are Green Investments. The New York Times 2022.

185. Handelsblatt. Energiewende kostet Stromkunden 28 Milliarden Euro. Handelsblatt 2015.

186. Smil, V. Germany's Energiewende, 20 Years Later; IEEE Spectrum: 25 November 2020, 2020.

187. Mushtaq, A.Q.; Afzal, M. Arab Spring: Its Causes and Consequences. Journal of the Punjab University Historical Society 2017, 30.

188. Syazli Saidin, M.I. Rethinking the 'Arab Spring': The Root Causes of the Tunisian Jasmine Revolution and Egyptian January 25 Revolution. International Journal of Islamic Thought 2018, 13, 69-79.

189. Uekötter, F. The Greenest Nation? A New History of German Environmentalism; MIT Press: Cambridge 2014.

190. Esping-Andresen, G.; Korpi, W. Social Policy as Class Politics in Post-War Capitalism. Scandinavia, Austria, and Germany. In Order and Conflict in Contemporary Capitalism, Goldthorpe, J., H., Ed. Oxford University Press: Oxford, 1984; pp. 180208.

191. Hernandez, A.M.; Prakoso, Y.T.B. The Learning Activation Approach-Understanding Indonesia's Energy Transition by Teaching It. Energies 2021, 14, 5224, doi:https://doi.org/10.3390/en14175224.

192. TWI2050. Innovations for Sustainability. Pathways to an efficient and post-pandemic future. Report prepared by The World in 2050 initiative; International Institute for Applied Systems Analysis: Laxenburg, Austria, 2020.

193. Baumeister, H.; Meier-Berberich, J. Chancen für den ÖPNV im ländlichen Raum durch Digitalisierung. Verkehr und Technik 2018, 8, 1-4.

194. Meyer, K.; Hochfeld, C. Klimaschutz 2030: Maßnahmen zur Erreichung des Sektorsziels im Verkehrsbereich; Agora Verkehrswende: Berlin, 2018.

195. UBA. Erneuerbare Energien in Deutschland 2020. Daten zur Entwicklung im Jahr 2020; Umweltbundesamt: 2021.

196. UBA. Treibhausgasemissionen sinken 2020 um 8,7 Prozent. In Positiver Trend der Vorjahre setzt sich fort / 40,8 Prozent Rückgang seit 1990, Gemeinsame Pressemitteilung von Umweltbundesamt und Bundesumweltministerium: Berlin, 2021.

197. Smyrgała, D. Fukushima and Energiewende: Impact on structure of power generation. Energy Sources, Part B: Economics, Planning, and Policy 2017, 12, 332-337, doi:10.1080/15567249.2015.1122679.

198. Glastra, K.; Rüdinger, A. Wahrnemung des Nachbarn in Zeiten der Krise. In In guter Gesellschaft. Die deutsche Energiewende und ihr Echo in Frankreich, Demesmay, C., Pütz, C., Stark, H., Eds. Nomos: Baden Baden, 2016; pp. 191-202. 
199. Bundesnetzagentur. Monitoring Bericht 2020; Bundesnetzagentur: Bonn, 2020.

200. Černoch, F.; Osička, J. 'Emotional, Erratic, Anti-Arithmetic and Deeply Consequential': The Energiewende as Seen from the Czech Republic. In Proceedings of ECPR General Conference, Wroclaw, Poland, 4-7 September 2019.

201. Müller, G. Deutsche Energiewende ist kein Vorbild. Neue Zürcher Zeitung 25 January 2017, 2017.

202. Uken, M. Deutschland nervt Polen mit der Energiewende. Zeit 1 December 2011, 2011.

203. Kriegler, E.; Weyant, J.P.; Blanford, G.J.; Krey, V.; Clarke, L.; Edmonds, J.; Fawcett, A.; Luderer, G.; Riahi, K.; Richels, R., et al. The role of technology for achieving climate policy objectives: overview of the EMF 27 study on global technology and climate policy strategies. Climate Change 2014, 123, 353 - 367.

204. Agora-Verkehrswende. Mit der Verkehrswende die Mobilität von morgen sichern. 12 Thesen zur Verkehrswende; 2017. 